\title{
OCCUPATION-LEVEL INCOME SHOCKS AND ASSET RETURNS: THEIR COVARIANCE AND IMPLICATIONS FOR PORTFOLIO CHOICE
}

\author{
Steven J. Davis \\ Paul Willen \\ Working Paper 7905 \\ http://www.nber.org/papers/w7905 \\ NATIONAL BUREAU OF ECONOMIC RESEARCH \\ 1050 Massachusetts Avenue \\ Cambridge, MA 02138 \\ September 2000
}

Prepared for "Innovations in Managing the Financial Risks of Retirement," a conference co-hosted by the Pension Research Council and the Financial Institution Center at The Wharton School of the University of Pennsylvania on May 1-2, 2000. We thank Deborah Lucas, Olivia Mitchell, Stephen Zeldes and other conference participants for helpful comments. Jeremy Nalewaik provided valuable research assistance. Davis gratefully acknowledges research support from the University of Chicago Graduate School of Business. The views expressed herein are those of the authors and not necessarily those of the National Bureau of Economic Research.

(C) 2000 by Steven J. Davis and Paul Willen. All rights reserved. Short sections of text, not to exceed two paragraphs, may be quoted without explicit permission provided that full credit, including $\mathbb{C}$ notice, is given to the source. 
Occupation-Level Income Shocks and Asset Returns:

Their Covariance and Implications for Portfolio Choice

Steven J. Davis and Paul Willen

NBER Working Paper No. 7905

September 2000

JEL No. G11, D91, D52, J30

\section{$\underline{\text { ABSTRACT }}$}

This paper develops and applies a simple graphical approach to portfolio selection that accounts for covariance between asset returns and an investor's labor income. Our graphical approach easily handles income shocks that are partly hedgable, multiple risky assets, many periods and life cycle considerations.

We apply the approach to occupation-level components of individual income innovations estimated from repeated cross sections of the Current Population Survey. We characterize several properties of these innovations, including their covariance with aggregate equity returns, long-term bond returns and returns on several other assets. Aggregate equity returns are uncorrelated with the occupation-level income innovations, but a portfolio formed on firm size is significantly correlated with income innovations for several occupations, and so are selected industry-level equity portfolios.

An application of the theory to the empirical results shows (a) large predicted levels of risky asset holdings compared to observed levels, (b) considerable variation in optimal portfolio allocations over the life cycle, and (c) large departures from the two-fund separation principle.

Steven J. Davis

Graduate School of Business

The University of Chicago

1101 East $58^{\text {th }}$ Street

Chicago, IL 60637

and NBER

sjd@gsbsjd.uchicago.edu
Paul Willen

Graduate School of Business

The University of Chicago

1101 East $58^{\text {th }}$ Street

Chicago, IL 60637 


\section{Introduction}

This paper develops and applies a simple graphical approach to portfolio selection that accounts for covariance between asset returns and an investor's labor income. Our graphical approach easily handles the realistic case in which income shocks are partly, but not fully, hedgable. ${ }^{1}$

We first show how covariance between income shocks and asset returns and persistence in the shocks affect portfolio choice over the life cycle. Next, we estimate the covariance and persistence parameters for occupation-level components of individual income using data from the Current Population Survey. After extracting the occupationlevel components of individual income innovations, we investigate their covariance with aggregate equity and bond returns, selected industry-level equity returns and the returns on portfolios formed on firm size and book-to-market equity values. We then apply the theoretical framework to the empirical results to calculate optimal portfolio allocations over the life cycle for selected occupations.

Our graphical approach captures several factors that influence portfolio choice over the life cycle: the drawdown of human capital as a worker ages, the impact of labor income innovations on the present value of lifetime resources, the increase in an investor's effective risk aversion as income smoothing ability declines with age, and systematic life cycle variation in the covariance between labor income shocks and asset returns. Each of these factors affects an investor's optimal level of risky asset holdings, as we show below.

According to the two-fund separation principle of traditional mean-variance portfolio analysis, every investor holds risky financial assets in the same proportions - only the level of holdings differs among investors. We show why and how that principle breaks

\footnotetext{
${ }^{1}$ Bodie, Merton and Samuelson (1992) derive analytical solutions for portfolio choice in a continuous time finite horizon setting with fully hedgable labor income risks. Much other work adopts computationally intensive approaches to the portfolio implications of unhedgable or partly hedgable labor income risks. See, for example, Cocco, Gomes and Maenhout (1999) for analysis in a finite horizon setting and Heaton and Lucas (1997), Viceira (1998) and Haliassos and Michaelides (1999) in infinite horizon settings.
} 
down when an investor has a risky income stream (from work or business ownership) that is correlated with asset returns. We quantify this breakdown and several contributory factors. Our application of the theory shows that even moderate covariances between income shocks and asset returns can drive large differences between optimal portfolio shares and the shares implied by a more traditional approach that ignores labor income or other sources of income from nonmarketable assets.

The chief empirical inputs into our theoretical framework include the first two moments of the asset return distribution and the covariance between income shocks and asset returns. While asset returns themselves receive enormous attention from researchers, only a handful of previous studies investigate their covariance with labor or proprietary business income. Campbell et al. (1999) consider the covariance between aggregate equity returns and the permanent component of household income for three education groups. Davis and Willen (2000) investigate the issue using a synthetic panel approach to demographic groups defined in terms of sex, educational attainment and birth cohort. Although based on rather different empirical designs, both studies find that the correlation between labor income shocks and equity returns rises with education. Heaton and Lucas (2000) highlight the positive correlation between equity returns and the income of self-employed persons. ${ }^{2}$

Previous empirical research on the covariance between income shocks and asset returns relies on panel data sets or synthetic panels constructed from repeated cross sections. This paper pursues a somewhat different empirical approach. In particular, we rely on the repeated cross-section structure of the Current Population Survey to extract mean occupation-level income shocks, while controlling for a host of observable worker characteristics. We then focus the rest of the empirical investigation on the properties of the occupation-level shocks and their covariance with asset returns.

\footnotetext{
${ }^{2}$ Other studies investigate the issue at a more aggregated level in an international setting. Botazzi, Pesenti and van Wincoop (1996) consider the covariance of national labor income shocks with financial asset returns, and Baxter and Jermann (1997) consider their covariance with the returns on hypothetical claims to a country's capital stock. Davis, Nalewaik and Willen (2000) consider the covariance between national output shocks and a variety of domestic and foreign asset returns for 18 industrialized countries.
} 
Our empirical approach has less demanding data requirements than panel-based approaches. It is also highly flexible in the sense that one can easily focus the empirical lens on any type of income shock that can be tied to observable characteristics of individuals, households or businesses. We consider occupation-level income shocks in this paper, but the same method can be applied to income shocks related to industry, location, firm size and worker characteristics like education, experience and job tenure. Because its starting point is a standard human capital earnings regression fit to crosssectional data, our approach offers a natural bridge between labor economics and finance.

The paper proceeds as follows. Section 1 develops the graphical approach in a twoperiod setting and explains how to handle multiple risky assets. Section 2 extends the graphical analysis to a many-period setting and analyzes several determinants of life cycle variation in optimal portfolio choice. Section 3 describes the data we use to identify occupation-level income innovations. Section 3 also characterizes the magnitude and persistence of the occupation-level income innovations. Section 4 investigates the covariance between the occupation-level income innovations and a variety of asset return measures. Section 5 draws on the empirical results in Sections 3 and 4 to implement the theoretical framework developed in Sections 1 and 2. We calculate optimal portfolio allocations for several occupations under various assumptions about investor age and risk aversion, asset returns and their covariance with labor income. We use the examples to illustrate life cycle variation in optimal portfolio allocations and the breakdown of twofund separation.

\section{Portfolio Choice with Risky Labor Income: A Graphical Approach}

This section develops a graphical approach to portfolio choice when investors face labor income shocks that are correlated with asset returns. Our treatment generalizes the popular mean-variance framework for portfolio analysis to cover the case of risky labor income. When labor income shocks are uncorrelated with asset returns, optimal portfolio allocations exhibit two-fund separation according to our analysis, just as they do in standard mean-variance analyses. More generally, when labor income innovations are 
correlated with asset returns, two-fund separation breaks down. We explain why and derive the implications for portfolio choice and investor utility.

We first develop the graphical approach in a two-period setting, which is easy to grasp and rich enough to illustrate many of the key points. Section 2 extends the approach to a life cycle setting with many periods. Some new issues arise in the many-period life cycle setting, but all of the key points from the two-period setting carry over.

Some mathematical details are contained in the appendix. Willen (1999) and Davis and Willen (2000) provide a more thorough development of the mathematical analysis. Along with Davis, Nalewaik and Willen (2000), they also consider asset pricing and risk sharing implications of the underlying theoretical model. This paper restricts attention to portfolio choice.

\subsection{A Two-Period Setting}

Consider an investor $h$ who lives for two periods $(t=0,1)$ and initially has no financial assets. This period she receives labor income $y_{0}^{h}$, and next period she receives stochastic labor income $\tilde{y}_{1}^{h}$. Expected income next period is $E\left(\tilde{y}_{1}^{h}\right)=\bar{y}_{1}^{h}$, and the income innovation is $\eta_{1}^{h}=\tilde{y}_{1}^{h}-\bar{y}_{1}^{h}$. Our investor has access to two financial assets: asset 0 is a riskless bond with certain gross return $R_{0}$; asset 1 is a risky security with uncertain gross return $\tilde{R}_{1}$. We assume that labor income innovations $\eta_{1}^{h}$ and risky asset returns $\tilde{R}_{1}$ are jointly normally distributed. Investor $h$ allocates $\omega_{0}^{h}$ to the riskless asset and $\omega_{1}^{\mathrm{h}}$ to the risky asset.

Let $c_{0}^{h}$ and $\tilde{c}_{1}^{h}$ denote first- and second-period consumption. The intertemporal budget constraint (in expected value terms) follows from the definitions above:

$$
\mathrm{c}_{0}^{\mathrm{h}}+\frac{1}{R_{0}} \mathrm{E}\left(\tilde{c}_{1}^{h}\right)=\mathrm{y}_{0}^{h}+\frac{1}{R_{0}} \mathrm{E}\left(\tilde{y}_{1}^{h}\right)+\frac{1}{R_{0}}\left(\mathrm{E}\left(\tilde{R}_{1}\right)-R_{0}\right) \omega_{1}^{h}=Y_{0}^{h}+\frac{1}{R_{0}}\left(\mathrm{E}\left(\tilde{R}_{1}\right)-R_{0}\right) \omega_{1}^{h}=W^{h}
$$

where $Y^{h}$ is the expected present value of lifetime labor income discounted at the risk-free rate ("human wealth"), and $W^{h}$ is total wealth.

Let the primitive utility function over $c_{0}^{h}$ and $\tilde{c}_{1}^{h}$ be time separable, and assume that 
the felicity functions defined over period consumption have the exponential form, - $\exp \left(-\mathrm{A}^{\mathrm{h}} \mathrm{c}\right)$, where $A>0$ governs the degree of risk aversion. This functional form implies constant absolute risk aversion ("CARA") in the face of wealth shocks, although it is easy to handle variation in risk aversion across persons or over the life cycle. As a convenience, assume also that the subjective discount rate equals the riskless rate. Under these conditions, we can write the present discounted value of utility as a function of current wealth and the variance of future consumption:

$$
U^{h}\left(W^{h}, V^{h}\right)=-\frac{1}{a A^{h}} \exp \left\{-a A^{h}\left(W^{h}-\frac{A^{h}}{2 R_{0}} V^{h}\right)\right\}
$$

where $A^{h}$ measures absolute risk aversion, $a=1 / R_{0}$ is an annuitization factor, and $V^{h}=\operatorname{var}\left(c_{1}^{h}\right)$.

\subsection{Indifference Curves}

Figure 1 shows indifference curves generated from equation (2). Each curve traces out combinations of wealth and consumption variance that leave utility unchanged. As one moves up and to the left, utility increases. The upper panel of Figure 1 shows, for a fixed degree of risk aversion, indifference curves that correspond to different levels of human wealth. The lower panel shows, for a fixed level of human wealth, indifference curves that correspond to different degrees of risk aversion. Greater risk aversion steepens the slope of the indifference curve, because a more risk averse investor requires greater compensation for added consumption variance in order to maintain a given utility level.

Two aspects of these indifference curves merit attention. First, the indifference curves are straight lines - the tradeoff between wealth and consumption variance depends neither on the level of wealth nor the variance of consumption. ${ }^{3}$ Second, the indifference curves in the top panel are parallel. In other words, an increase in wealth increases utility

\footnotetext{
${ }^{3}$ This feature is unique to CARA utility. With other preferences, the curvature of the indifference curves depends on both the level of wealth and the consumption variance. Specifically, for the common isoelastic specification (constant relative risk aversion), the slope of the indifference curves rises with the variance of consumption and decreases with wealth.
} 
by the same amount regardless of the variance level. Thus the change in certainty equivalent wealth - the movement along the y-axis - measures the amount of first-period wealth necessary to compensate an investor for a move from one indifference curve to another.

\subsection{Feasible Sets}

Figure 2 and Figure 3 show "feasible sets" - combinations of wealth and consumption variance that can be implemented by some feasible portfolio strategy - under various assumptions about investment opportunities and investor income. For any risky asset amount $\omega_{1}^{h}$, equation (1) gives the corresponding level of total wealth. The variance of consumption is

$$
V^{h}=\operatorname{var}\left(\tilde{y}_{1}^{h}\right)+\left(\omega_{1}^{h}\right)^{2} \operatorname{var}\left(\widetilde{R}_{1}\right)+2 \omega_{1}^{h} \operatorname{cov}\left(\tilde{\eta}_{1}^{h}, \tilde{R}_{1}\right)
$$

In traditional mean-variance analysis, the portfolio choice set is the same for everyone and depends only on asset prices and the covariances of assets with one another. Here, the feasible set depends additionally on the characteristics of investor income and thus differs across investors. Specifically, the feasible set depends on the level of human wealth, $Y^{h}$, the variance of labor income, $\operatorname{var}\left(\tilde{\eta}_{1}^{h}\right)$, and the covariance between labor income shocks and asset returns, $\operatorname{cov}\left(\tilde{\eta}_{1}^{h}, \widetilde{R}_{1}\right)$.

In the case with one risky asset, we can read portfolio holdings directly from Figure 2 and Figure 3. By equation (1) and the definition of $Y^{h}, \omega_{1}^{h}=\left(W^{h}-Y^{h}\right) /\left(\mathrm{E}\left(\widetilde{R}_{1}\right)-R_{0}\right)$. Assuming positive excess returns on the risky asset, $W^{h}=Y^{h}$ corresponds to no investment in risky assets, $W^{h}>Y^{h}$ corresponds to a long position, and $W^{h}<Y^{h}$ corresponds to a short position. We report $\omega_{1}^{h}$ on the right side of the plot.

The upper panel of Figure 2 shows feasible sets for different levels of expected future income (and human wealth), holding all else equal. The key thing to note about this picture (and many of the subsequent ones) is that the level of wealth affects the position but not the shape of the feasible set.

The lower panel of Figure 2 shows feasible sets for different levels of income variance, holding the covariance with asset returns constant and equal to zero. This panel 
captures the effect of so-called "background risk". The bigger the labor income variance, the further to the right the curve moves. However, as with wealth differences, the shape of the feasible set stays exactly the same. This result carries over to the case of non-zero correlation between labor income and asset returns, as we show below.

The upper panel of Figure 3 shows that a change in the expected return premium on the risky asset ("risk premium") changes the shape but not the location of the feasible set. As the risk premium goes up, there is a bigger wealth payoff to taking on more consumption variance.

The lower panel of Figure 3 shows how the covariance between labor income shocks and asset returns affects the feasible set. The middle curve illustrates the case of no covariance between labor income and asset returns. Note that as risky asset holdings move away away from zero in either direction, consumption variance rises. Compare this outcome with the lower curve, where we set the correlation between labor income and asset returns at 0.5. Here, as we increase investment in the risky asset above zero, the variance of consumption increases at a much faster rate per unit of wealth than in the zero-correlation case. However, as we decrease investment in the risky asset below zero (take a short position), the variance actually drops. By shorting the risky asset, the investor achieves some hedging of risky labor income. The upper curve shows the feasible set when the correlation between labor income and asset returns is -0.5. Now, raising investment in the risky asset above zero reduces the variance of consumption. In this case, there is no trade-off between risk and return at zero investment, and the investor can get lower risk and higher return. It is worth reiterating that covariance changes only the location and not the shape of the feasible set.

\subsection{Portfolio choice}

We solve for the optimal combination of wealth and variance, and thus the optimal portfolio, by combining the feasible set and the indifference curves in the usual way. The top panel of Figure 4 shows portfolio choice in the simplest example with a zero correlation between labor income shocks and asset returns. The investor chooses the point on the feasible set tangent to the highest attainable indifference curve. The optimal portfolio is the distance $E^{\prime} O^{\prime}$ on the right hand axis and is a roughly $\$ 50,000$ long 
position. It is important to recognize that in the absence of any correlation between labor income shocks and asset returns, our investor can implement the minimum variance consumption allocation by holding zero risky assets. This minimum variance portfolio $M$ ' is the same as the endowment portfolio $E$ ' when the investor begins period 0 with no holdings of risky financial assets.

The lower panel of Figure 4 shows portfolio choice when the correlation between labor income is positive (and fairly high). The optimal investment (the segment $E^{\prime} O^{\prime}$ on the right axis) in the risky asset is around $\$ 20,000$, less than half the optimal investment when the correlation is zero.

We can decompose this portfolio choice decision in terms of the investor's desired and endowed exposures to the risky asset. Recall that for a given expected return premium on the risky asset, the shape of the feasible set is invariant. Since the slope of the indifference curves is also invariant, the position of the optimal point relative to the minimum variance point is always the same. ${ }^{4}$ In other words, the distance $M^{\prime} O^{\prime}$ is invariant to anything except the expected return premium on the risky asset and the investor's risk aversion. We call this distance the "desired exposure", because it reflects the sensitivity of consumption to asset return risk at the investor's optimal portfolio allocation. It can also be interpreted as risky asset demand in the absence of any correlation between labor income and asset returns.

Correlation between labor income and asset returns means that an investor is endowed with a non-zero exposure to the risky asset. Hence, we call the distance $M^{\prime} E^{\prime}$ ' the "endowed exposure." An investor's optimal portfolio allocation - her demand for risky assets - equals the difference between the endowed and desired exposures.

We now see that endowed exposure is a key link between risky labor income and portfolio choice. Using the concept of endowed exposure, we can convert a portion of

\footnotetext{
${ }^{4}$ This is only true for CARA utility. In general, since the slope of the indifference curves depends on the variance of consumption, the location of the feasible set matters, not just its shape. For example, if "background risk" changes (as in the lower panel of Figure 2), portfolio choice will be unaffected in a model with CARA preferences. With isoelastic utility, an increase in background risk increases the slope of the indifference curves. As a result, investors with more background risk hold less of the risky asset, a phenomenon sometimes described as "crowding out." See Bodie, Merton and Samuelson (1992).
} 
labor income risk into traded asset risk. Portfolio managers typically have sophisticated ways of assessing desired exposure - as a function of age, income and risk tolerance. To figure out the optimal portfolio in the presence of labor income risk, one needs to bring endowed exposure into the picture. For this reason, a central goal of empirical research in this area is to estimate endowed exposure. Our analysis thus far shows that endowed exposure depends on the covariance between labor income shocks and asset returns. In a dynamic setting, endowed exposure also depends on the persistence of income shocks, as we show below.

Figure 4 demonstrates another key point about the role of labor income in risky asset choice: The welfare gains to trading the risky asset are more sensitive to the correlation between income shocks and asset returns than the demand for risky assets. To see this point, first recall that the distance between indifference curves along the y-axis equals the amount of wealth the investor requires to move from one indifference curve to another. Hence, the distance $E O$ in the upper panel of Figure 4 equals the additional wealth our investor requires to make her as well off with no trade in risky assets as with her optimal level of the risky asset. This amount is the distance between the minimum variance indifference curve and the optimal indifference curve for any investor with the same risk aversion facing the same risk premium. Now turn to the lower panel of Figure 4. The correlation between labor income and asset returns means that our investor wants to invest only half as much in the risky asset as she would in the case with certain labor income. One might guess that her gains from trading the risky asset are also about half as large. Figure 4 shows that such a guess would be wrong. Instead, the gains from trading the risky asset, the distance $E O$ on the y-axis, are only about fifteen percent as large as in the case with certain labor income (the distance $M O$ ).

Why do the welfare gains from trading the risky asset drop off more rapidly than risky asset demand when we raise the correlation between income shocks and asset returns? Because the slope of the feasible set drops as consumption variance rises. Small investments in the vicinity of the minimum variance point generate huge wealth increases per unit of additional variance. But those benefits are "used up" by the endowed exposure, when income shocks and asset returns are positively correlated. At the 
endowed exposure, the additional exposure from a small investment in the risky asset has a much worse trade-off.

This analysis suggests that, if there is a fixed cost to trading risky financial assets, even a moderate positive correlation might be enough to dissuade potential investors from participating in risky asset markets. For example, the lower panel of Figure 5 shows that a correlation of 0.2 is enough to wipe out half the benefits of trading risky financial assets. A correlation of 0.2 corresponds to an $R^{2}$ value of only .04 in a regression of labor income shocks on asset returns. ${ }^{5}$

The top panel of Figure 5 shows portfolio choice when labor income is negatively correlated with asset returns. Here, "endowed exposure" is negative. By investing $M$ ' $E$ ' in the risky asset, our investor achieves minimum variance. Then she adds the segment $M^{\prime} O^{\prime}$ so that total investment is $E^{\prime} O^{\prime}$. When labor income is negatively correlated with asset returns, ignoring it leads one to underinvest in risky assets. The welfare effects of financial markets are now much more pronounced than the portfolio effects. The actual investment (the distance $E^{\prime} O^{\prime}$ ) is only 50 percent larger than it would be in the certain income case (the distance $M^{\prime} O^{\prime}$ ), but the gains from investing with a correlation of -.5 $(E O)$ are more than twice as large as with zero correlation $(M O)$.

Although Figure 4 and Figure 5 involve a single risky asset, they help understand the potential for a breakdown in two-fund separation when labor income is correlated with asset returns. In traditional mean-variance portfolio analysis, every investor has the same (zero) endowed exposure to risky assets. This assumption is essential for the derivation of the two-fund separation theorem that characterizes optimal portfolios of many risky assets in the traditional analysis. ${ }^{6}$ The two-fund separation result carries over to the case of risky labor income, provided that labor income shocks are uncorrelated with (all) asset returns. But, when income shocks covary with asset returns, investors are endowed with certain exposures to risky financial assets. If the correlation structure between labor income shocks and asset returns differs among investors, then so do their endowed

\footnotetext{
${ }^{5}$ Incidentally, Davis and Willen (2000) find correlations between labor income shocks and returns on the S\&P 500 of roughly that magnitude for college-educated men and women.

${ }^{6}$ For an in-depth treatment of portfolio separation theorems, see chapter 6 in Ingersoll (1987).
} 
exposures. Hence, the optimal portfolio shares for risky assets differ among investors, even if the other conditions for two-fund separation continue to hold. We more fully develop this point in the next subsection.

\subsection{Multiple risky assets}

Now consider the portfolio choice problem when there are multiple risky assets. For simplicity, begin with the case of two risky assets that have uncorrelated returns.

Adding a second asset (weakly) increases the size of the feasible set. Recall that the excess expected return and the variance of the risky asset determine the shape of the feasible set in the case with one risky asset. Analogously, when there are multiple risky assets, expected excess returns and the variance-covariance matrix of asset returns determine the shape of the feasible set. As before, covariance between asset returns and labor income affects the location of the feasible set, but not its shape.

Figure 6 shows feasible sets for various covariance structures between labor income shocks and asset returns. The two numbers next to each curve report covariances with the first and second assets, respectively. As before, negative covariances push the feasible set up and to the left, while positive covariances push it down and to the left.

We can still use indifference curves to find the optimal combinations of wealth and consumption variance, but it is not quite as easy to read the optimal portfolio allocations from the picture alone. To see why, consider the curves marked $(0,0)$ and $(0.5,-0.5)$ in Figure 6 . In both cases, the minimum variance points involve no net investment in risky assets. In the $(0,0)$ case, the minimum variance consumption allocation involves no gross investment in either asset. But in the $(0.5,-0.5)$ case, the minimum variance consumption allocation involves countervailing negative and negative positions in the two assets.

Fortunately, there is an easy adaptation of the graphical algorithm developed above to the case with multiple risky assets. When the risky asset returns are uncorrelated, the portfolio selection algorithm works as follows:

1. Consider asset 1 , and use the methods described above to calculate optimal holdings as if there were no other risky financial assets.

2. Consider asset 2, assuming that the endowment consists of the labor income stream and the optimal holdings of asset 1 from Step 1. Use the methods described above to calculate the optimal holdings of asset 2 . 
In other words, the solution to Step 1 is the starting point for Step 2, and the optimal portfolio allocations can be constructed by a sequential application of the techniques used in the case of a single risky asset.

Figure 7 illustrates this sequential graphical solution for two investors who differ with respect to correlations between labor income shocks and asset returns. In the top panel, the investor's labor income is uncorrelated with both asset returns. Thus, her minimum variance point and her endowment point are the same, denoted $M 1^{\prime}=E 1^{\prime}$ in the figure. $O 1^{\prime}$ is the optimal portfolio from step 1 in the algorithm. We then set $E 2^{\prime}=O 1^{\prime}$ as the new endowment point and solve for the optimal holdings of asset 2, which is given by the distance $O 2^{\prime}$ E2'.

The bottom panel illustrates the sequential procedure for an investor who has a correlation of 0.3 with asset 1 and -0.2 with asset 2. Again, $O 1^{\prime}$ ' is the investor's asset 1 allocation from step 1 in the algorithm, and $\mathrm{O2}^{\prime} \mathrm{OI}$ ' is the asset 2 allocation from step 2. Obviously, this algorithm extends readily to an arbitrary number of uncorrelated risky assets.

Note that the concepts of desired and endowed exposure continue to apply in the multiple asset case. For the two investors in Figure 7, desired exposures are the same and given by the distance $M 1^{\prime} O 1^{\prime}$ for asset 1 and $M 2^{\prime} O 2^{\prime}$ for asset 2 . Endowed asset exposures are zero for the investor in the top panel. For the investor in the bottom panel, the endowed exposures are $E 1^{\prime} M 1$ ' in asset 1 and $E 2{ }^{\prime} M 2^{\prime}$ in asset 2. ${ }^{7}$

Figure 7 illustrates the failure of the two-fund separation principle when multiple asset returns are correlated with labor income. Optimal risky asset allocations equal desired minus endowed exposures, so that heterogeneity in endowed exposures leads to heterogeneity in optimal portfolios. The endowed asset exposures differ between the two investors in Figure 7, so that their optimal portfolio shares also differ, even though both investors have identical desired exposures. Section 5 below explores the quantitative significance of these deviations from two-fund separation in some concrete examples.

\footnotetext{
${ }^{7}$ Given asset returns that are uncorrelated with labor income shocks, endowed exposures are unaffected by how we order the assets in the portfolio construction algorithm.
} 
The simplicity of the multi-asset portfolio construction algorithm rests partly on the assumption of zero correlation among asset returns. In practice, risky asset returns are correlated, often highly so. Hence, we need to generalize the portfolio construction algorithm to handle assets with correlated returns. This is easily done. The basic idea is to first construct a residual version of the second asset that is uncorrelated with the first asset, then apply the sequential algorithm above to find the optimal portfolio of the first asset and the uncorrelated residual asset. Given this solution, we can then calculate the optimal combination of the original first and second assets.

Here are the detailed steps of the portfolio construction algorithm:

1. Same as before.

2. Consider the Ordinary Least Squares (OLS) regression,

$$
\tilde{R}_{2}=\alpha+\beta \tilde{R}_{1}+\tilde{\rho}
$$

and create a residual asset by investing

(a) 1 dollar in asset 2 ,

(b) $-\beta$ dollars in asset 1 , and

(c) $\beta$ dollars in the riskless assets.

The payoff on this residual asset is $\tilde{r}_{2}=\alpha+\beta R_{0}+\tilde{\rho}$.

3. Consider the residual asset, assuming that the endowment consists of the labor income stream and the optimal holdings of asset 1 from Step 1. Use the same methods as before to calculate the optimal holdings of the residual asset.

4. The optimal holdings of asset 2 equal the optimal holdings of the residual asset from Step 3. The optimal holdings of asset 1 equal the amount computed in Step 1 minus $\beta$ times the optimal holdings of the residual asset computed in Step 3.

Two observations are important for understanding why this algorithm works.

First, OLS regression assures that $\operatorname{cov}\left(\widetilde{R}_{1}, \tilde{\rho}\right)=0$; in other words, the first asset and the residual asset are uncorrelated by construction. Second, the opportunity set facing the investor is the same whether she trades (a) asset 1, asset 2 and the riskless asset or (b) asset 1, the residual asset and the riskless asset. Thus, any solution to the portfolio problem calculated using assets (b) is equivalent to a solution calculated using assets (a). 
As a final remark on the multi-asset case, consider again the concept of endowed exposure and its relationship to an optimal portfolio. The endowed exposure to asset 2 for an investor who trades asset 1 depends on the correlation between the residual asset and labor income. This correlation may be quite different from the correlation calculated by ignoring asset 1 . To illustrate this point, Table 1 considers a two-asset world. Both assets have unit variance as does labor income. Asset 1 has a correlation of 0.5 with labor income and asset 2 has a correlation of 0.25 . The first column of Table 1 shows alternative values for the correlation between the returns on asset 1 and the original asset 2. Column three shows the implied correlation between the 'residual' version of asset 2 and labor income. The correlation of the residual asset 2 with labor income varies from minus 0.42 to positive 0.25 , depending on the correlation between the raw asset returns. Hence, in a multi-asset setting, one cannot use simple correlations between labor income and asset returns to infer whether an investor's hedge portfolio involves long or short positions in particular assets.

\section{Many Periods and Other Extensions}

This section extends the graphical approach to encompass many periods in order to analyze portfolio choice over the life cycle. We first identify several additional effects that arise because of many periods and life cycle considerations. ${ }^{8}$ We then revisit the portfolio analysis to treat these issues. We briefly discuss a few other issues and extensions.

\subsection{Life Cycle Considerations}

Real-world investors live for many years, not just two periods, and they adjust their portfolios over time for a variety of reasons. As a worker-investor ages, the retirement horizon gradually draws closer and the overall planning horizon shrinks. Income

\footnotetext{
${ }^{8}$ Our discussion ignore tax considerations, which is itself a large topic. For other recent discussions of portfolio allocation over the life cycle, see Ameriks and Zeldes (2000), Campbell et al. (1999), Coco, Gomes and Maenhout (1999) and Jagannathan and Kocherlakota (1996).
} 
fluctuates in partly predictable, partly unpredictable ways. The opportunity cost of investment funds tends to decline with age as a worker-investor accumulates financial assets, housing equity and other marketable forms of wealth.

These basic considerations influence portfolio choice in several ways:

Smoothing of Income Shocks: An investor who anticipates many additional years of life can smooth the consumption effects of income shocks over a long horizon. Conversely, as an investor ages and her planning horizon shrinks, the scope for smoothing income shocks diminishes. As a result, tolerance for income risk declines.

Magnification of Labor Income Shocks: Good news about current labor income typically raises expected future labor income, too, and vice versa for bad news. Hence, a shock to current labor income implies a larger shock to the present value of lifetime labor income - i.e., to the value of the worker's human capital. This magnification effect implies that the covariance between asset returns and the value of human capital is some multiple of the covariance between asset returns and labor income innovations.

Human Capital Drawdown: The discounted present value of future labor income tends to decline with age, simply because fewer years of work remain. In other words, a worker-investor naturally draws down her human capital over time, even if her annual labor income continues to grow. This drawdown effect means that the covariance between asset returns and lifetime labor income tends to decline with age. Put differently, if risky asset returns are positively correlated with a worker's labor income innovations, then the worker's endowed exposure declines with age. ${ }^{9}$

\footnotetext{
${ }^{9}$ The drawdown of risky human capital also involves a decline in background risk as a worker-investor ages. Other things equal, background risk reduces the demand for risky assets when preferences exhibit constant relative risk aversion (Dréze and Modigliani, 1972). Hence, the decline in background risk caused by human capital drawdown can increase risky asset demand as a worker ages. Because the demand for risky financial assets is unaffected by background risk when preferences are exponential, this effect does not arise in our model if $A^{h}$ is age-invariant. However, the effect can be easily introduced by specifying a suitable pattern of life cycle variation in $A^{h}$.
} 
Changing Covariance: The covariance between labor income innovations and asset returns can vary with age for a variety of reasons. For example, technological developments may affect experienced and inexperienced workers differently. Recent hires may be more exposed to firm- and industry-specific demand shifts than workers with long tenure on the job. As yet another example, younger workers may find it easier to switch locations or careers following a layoff. Theory alone cannot tell us whether or how the covariance between asset returns and labor income innovations varies with age. That task requires detailed empirical study. Theory can inform us about the portfolio choice implications of any relationship between covariance and age uncovered by empirical research.

Declining Opportunity Cost of Funds: The opportunity cost of funds invested in risky financial assets declines over the life cycle for many, probably most, persons. For a young worker-investor with few assets other than human capital, the opportunity cost equals the interest rate on an unsecured loan. ${ }^{10}$ For an investor with housing equity but little financial wealth, the opportunity cost equals the interest rate on a home equity loan. And, for an investor with substantial liquid assets, the opportunity cost equals the rate of return on safe assets. The decline in the cost of funds over the life cycle is quite large relative to the expected return on risky financial assets, which implies a potentially large impact on the life cycle profile of risky asset holdings.

Diminishing Labor Supply Flexibility: In the face of uncertain income streams, prudent investors have a precautionary source of demand for safe assets that pay a certain rate of return. ${ }^{11}$ Other things equal, greater uncertainty about future income (or future consumption needs) raises the demand for precautionary holdings of safe assets. Labor supply flexibility affords an imperfect, but potentially attractive, substitute for these precautionary holdings, because a worker-investor can

\footnotetext{
${ }^{10}$ Or the implicit interest rate implied by the expected consumption growth rate, if the consumption Euler equation does not hold with equality.

${ }^{11}$ A "prudent investor" has a positive third derivative in the utility function defined over consumption. Most commonly used utility functions display this property, including the exponential utility function that underlies our analysis.
} 
compensate for unexpectedly low income by working longer or harder. However, the ability to respond in this way diminishes with age, because fewer years of work remain. This decline in lifetime labor supply flexibility with age reduces tolerance for risk and increases the attractiveness of safe investments. In this respect, diminishing labor supply flexibility works in the same direction as the income smoothing effect; the former effect involves the work horizon, while the latter involves the planning horizon.

Each of these effects is potentially important for certain classes of investors, and all generate life cycle variation in optimal portfolio allocations. The timing and extent of life cycle variation stemming from these effects are also likely to differ among investors. For example, human capital drawdown occurs earlier in life and more rapidly for construction laborers than for university professors. As another example, the empirical work below provides direct evidence that the magnification effect varies among occupations. In short, this discussion points to many reasons for cross-sectional heterogeneity and life cycle variation in optimal portfolios.

The first four effects identified above are easy to handle in a many-period extension of the two-period graphical analysis. We do not account for diminished labor supply flexbility, because our theoretical framework treats labor income as exogenous. ${ }^{12}$ Also, we devote little attention to life cycle variation in the opportunity cost of funds. We suspect that the opportunity cost of funds is a major determinant of cross-sectional and life cycle variation in risky asset holdings, but a full treatment of that issue is beyond the scope of this paper. We explore the matter in Davis et al. (2000).

It might seem that many periods and life cycle considerations necessarily make the portfolio problem much more complex, because any decision that affects asset holdings tomorrow influences future consumption and future investment. However, provided that the higher moments of the asset return distribution are nonstochastic, the two-period analysis and graphical treatment extend readily to a many-period setting. ${ }^{13}$

\footnotetext{
${ }^{12}$ See Bodie, Merton and Samuelson (1992) for an analysis of this effect.

${ }^{13}$ The assumption of nonstochastic return distributions is standard in the classic papers on dynamic portfolio selection; see, for example, Samuelson (1969). Davis and Willen (2000) show that a nonstochastic price of risk
} 


\subsection{The Portfolio Problem with Many Periods}

Consider an investor who lives $T$ additional periods and faces normally distributed asset returns and labor income shocks. The higher moments of the asset return distribution are nonstochstic. As before, the primitive utility function over consumption is time separable and has the exponential form. Define an operator that gives the present discounted expected value of a random sequence:

$$
P D V_{t}\left(\left\{\tilde{z}_{s}\right\}_{s=t+1}^{T}\right)=\sum_{s=t+1}^{T} \frac{1}{\Pi_{i=t+1}^{s} R_{0, i}} E\left(\tilde{z}_{s}\right)
$$

For convenience, we continue to assume that the rate of time preference equals the riskfree rate of interest.

In this setting, the intertemporal budget constraint is a multi-period analogue of equation (1):

$$
\begin{aligned}
\left.\mathrm{W}_{\mathrm{t}}^{\mathrm{h}}=\operatorname{PDV}\left(\tilde{\mathrm{y}}_{\mathrm{s}}^{\mathrm{h}}\right\}_{\mathrm{s}=\mathrm{t}}^{\mathrm{T}}\right)+\mathrm{R}_{0, \mathrm{t}} \omega_{0, \mathrm{t}-1}^{\mathrm{h}}+\tilde{\mathrm{R}}_{1, \mathrm{t}} \omega_{1, \mathrm{t}-1}^{\mathrm{h}}+\left(\mathrm{E}\left(\tilde{\mathrm{R}}_{1, \mathrm{t}+1}\right)-\mathrm{R}_{0, \mathrm{t}+1}\right) \omega_{1, \mathrm{t}}^{\mathrm{h}} \\
+\operatorname{PDV}\left(\left\{\left(\mathrm{E}\left(\tilde{\mathrm{R}}_{1, \mathrm{~s}}\right)-\mathrm{R}_{0, \mathrm{~s}}\right) \omega_{1, \mathrm{~s}-1}^{\mathrm{h}}\right\}_{\mathrm{s}=\mathrm{t}+2}^{\mathrm{T}}\right)
\end{aligned}
$$

The first term on the right side of (4) is the present value of current plus future labor income, discounted at the risk-free rate. The next two terms give the market value of the investor's portfolio of financial assets at the beginning of period $t$. The last two terms reflect the wealth effect of current and future opportunities to invest in an asset that has an expected return premium over the risk-free rate.

Although equation (4) looks complicated, two facts simplify matters greatly. First, at time $t$ an investor can only affect $W_{t}^{h}$ through her choice of $\omega_{1, t}^{h}$. Second, because neither wealth nor variance affects absolute risk aversion, future risky asset choices $\left(\omega_{1, s}^{h}\right.$, for $s>t$ ) do not depend on any decisions made today. In light of these two observations, investors choose portfolio allocations to maximize

$$
U^{h}\left(W_{t}^{h}, V_{t+1}^{h}\right)=-\frac{1}{a_{t}^{h} A^{h}} \exp \left\{-a_{t}^{h} A^{h}\left(W_{h t}^{h}-\frac{a_{t+1}^{h} A^{h}}{2 R_{0, t+1}} V_{t+1}^{h}\right)\right\}
$$

(ratio of excess returns to standard deviation of returns) is sufficient for a closed-form representation of the portfolio selection decision and, therefore, for the graphical representation developed in this paper. 
subject to (4), where $\mathrm{V}_{\mathrm{t}}^{\mathrm{h}}=\operatorname{var}_{\mathrm{t}-1}\left(\mathrm{c}_{\mathrm{t}}^{\mathrm{h}}\right)=\left(\mathrm{a}_{\mathrm{t}}^{\mathrm{h}}\right)^{2} \operatorname{var}_{\mathrm{t}-1}\left(\mathrm{~W}_{\mathrm{t}}\right)$ is the conditional variance of consumption at time $t-1$, and $a_{t}^{h}=1 / \operatorname{PDV}\left(\{1\}_{s=t}^{T}\right)$ is an annuitization factor. Except for the time subscripts, equation (5) looks very much like equation (2). Thus, we can again characterize the portfolio decision in wealth-variance space. Of course, the longer time horizon affects the investor's decision. In particular, the differences between $a_{1}$ and $a_{t}^{h}$ and between $V^{h}$ and $V_{t}^{h}$ reflect, respectively, the income smoothing and magnification effects that we identified above. We turn next to a fuller development of these points.

\subsection{The income smoothing effect and 'dynamic risk aversion'}

The shorter the planning horizon, the greater the utility loss caused by a single bad year for an investor. With only one more year to live, a \$50,000 investment loss means a $\$ 50,000$ cut in consumption during the last year of life. With a long time left to live, the investment loss can be spread over many years. Since investors ultimately care about consumption, and the marginal utility of consumption is declining, a given-size shock to wealth has larger utility consequences for an investor with a shorter planning horizon.

Recall from the two-period case that desired exposure depends only on absolute risk aversion (the slope of the indifference curves). The same property holds in the manyperiod case, but effective risk aversion becomes $A_{t}^{h}=a_{t}^{h} A^{h}$ where $A^{h}$ is the individualspecific measure of absolute risk aversion in the primitive utility function, and $a_{t}^{h}$ is the marginal propensity to consume (MPC) out of wealth. ${ }^{14}$ The MPC is positive and rises monotonically with age, eventually reaching unity in the last period of life. In this model, as in traditional permanent income models, a dollar shock to wealth is spread over the rest of life. The longer an investor has to live, the more years over which to spread a shock. We refer to $A_{t}^{h}$ as dynamic absolute risk aversion, because it changes over time as the investor ages and her planning horizon shrinks.

The lower panel of Figure 1 shows indifference curves for different levels of risk aversion. A picture showing different ages would look exactly the same - as an investor

\footnotetext{
${ }^{14} A^{h}$ can also be allowed to vary with age.
} 
grows older, dynamic absolute risk aversion rises and the indifference curves steepen. If the investor's feasible set remains unchanged, she should reduce her holdings of risky assets as she ages. ${ }^{15}$ Note, however, that we are talking about levels not proportions. As people age, total wealth $W_{t}^{h}$ tends to decline, so that investment in risky financial assets need not decline as a fraction of total wealth as an investor ages.

Financial wealth $\left(\omega_{0, t}^{h}+\omega_{1, t}^{h}\right.$ at time $\left.t\right)$ typically grows over an investor's working life, as she converts human capital into financial wealth for retirement. (Financial wealth also tends to grow with the coversion of expected future excess returns into realized excess returns.) Since financial wealth grows over her working life and the level of risky financial asset holdings shrinks, the optimal share of financial wealth in risky assets falls over the life cycle - just as financial planners recommend. ${ }^{16}$

To sum up, the two-period analysis applies to the many-period situation with respect to income smoothing effects, if one replaces $a_{1}$ with $a^{h}{ }_{t}$.

\subsection{The magnification effect and the variance of wealth}

In a dynamic model, a shock to current labor income conveys information about expected future income. Consider a tenure-track finance professor at a leading business

\footnotetext{
${ }^{15}$ This effect arise in any permanent-income type model. That is, the higher the marginal propensity to consume out of wealth, the larger the impact of a dollar shock to wealth on consumption. With CRRA preferences, absolute risk aversion falls at the same rate as wealth, so that the proportion of total wealth invested in the risky asset remains constant (conditional on the covariance, magnification and other life cycle considerations identified above). This constant-share implication of CRRA preferences is well known. However, since wealth falls (in expectation) over the life cycle, CRRA preferences also imply declining levels of risky asset holdings as an investor ages.

${ }^{16}$ On the advice of financial planners, see Canner, Mankiw and Weil (1998) and Ameriks and Zeldes (2000). Since Bodie, Merton and Samuelson (1992), many researchers have argued that the explanation in the text (growing financial wealth implies shrinking proportion in risky assets) is consistent with financial planner's advice. This is not quite correct - financial planners typically advise a falling proportion of wealth in risky assets even in retirement -- after the drawdown of human capital is complete. Consider the financial planner's advice related in Ameriks and Zeldes, "The longer you have to invest, the more time you have to weather the market's inevitable ups and downs." This statement is inconsistent with the human capital drawdown explanation, but it is the correct explanation for why the level of investment in risky assets should fall over the life cycle - suggesting that financial planners are mixing up levels and proportions.
} 
school. If she is denied tenure and takes a position on Wall Street as a result, her pay will immediately jump up, and her expected future pay will also increase (perhaps even more). With the bad(?) news about tenure, her wealth rises by the full amount of the increase in the present value of her lifetime labor income. A modest shock to current income may translate into a much more dramatic wealth shock.

This effect is reflected in the variance of wealth, which is proportional to $V_{t}^{h}$, the variance of consumption. An innovation to wealth can be written

$$
W_{t}^{h}-E_{t-1}\left(W_{t}^{h}\right)=\operatorname{PDV}_{\mathrm{t}}\left(\left\{\tilde{y}_{s}^{h}\right\}_{s=t}^{T}\right)-\operatorname{PDV}_{\mathrm{t}-1}\left(\left\{\tilde{y}_{s}^{h}\right\}_{s=t}^{T}\right)+\left(\tilde{R}_{1, t+1}-\mathrm{E}\left(\tilde{R}_{1, t+1}\right)\right) \omega_{1, t-1-1}^{h} \cdot
$$

If $\tilde{y}_{t}^{h}$ follows an autoregressive moving average (ARMA) process, then we can write

$$
\operatorname{PDV}_{\mathrm{t}}\left(\left\{\tilde{y}_{s}^{h}\right\}_{s=t}^{T}\right)-\operatorname{PDV}_{\mathrm{t}-1}\left(\left\{\tilde{y}_{s}^{h}\right\}_{s=t}^{T}\right)=\Psi_{t}^{h} \tilde{\eta}_{t}^{h}
$$

where $\widetilde{\eta}_{t}^{h}$ is the time- $t$ innovation in labor income, and $\Psi_{t}^{h}$ measures the wealth impact of unit innovation. When income obeys an ARMA proces, $\Psi_{t}^{h}$ summarizes the impact of a current income innovation on the present value of lifetime resources. ${ }^{17}$

Figure 8 illustrates the calculation of $\Psi_{t}^{h}$ for simple ARMA processes. The upper panel shows the impulse response function - i.e., the impact of an income innovation on expected income $n$ years in the future. If income follows a random walk, then a dollar increase in an investor's labor income today implies a dollar increase for the rest of her life. In contrast, if income follows a white noise process, the effect at any future date is zero. In Section 3.3, we find that mean labor income among Truck Drivers is fairly close to a random walk, while it is much closer to white noise among Electrical Engineers.

The wealth impact of a current income innovation is the discounted sum of the current and expected future changes in labor income over the rest of the investor's working life. This point is illustrated in the lower panel. As a person's retirement horizon nears, the wealth effect of a shock to current income gets smaller.

Recalling the proportionality between the wealth and consumption variances, the variance of consumption can be written as

${ }^{17}$ Formally, any ARMA process can be represented by an $M A(\infty)$. The MA coefficients $\psi_{\mathrm{i}}^{\mathrm{h}}$ tell us that 


$$
V_{t}^{h}=\left(a_{t}^{h}\right)^{2}\left[\operatorname{var}\left(\Psi_{t}^{h} \widetilde{\eta}_{1}^{h}\right)+\left(\omega_{1, t-1}^{h}\right)^{2} \operatorname{var}\left(\widetilde{R}_{1, t}\right)+2 \omega_{1, t-1}^{h} \operatorname{cov}\left(\Psi_{t}^{h} \widetilde{\eta}_{t}^{h}, \widetilde{R}_{1, t}\right)\right]
$$

Compare equation (6) with equation (3), the variance of second-period wealth in the twoperiod model. The only difference is the multiplication of the shock by $\Psi_{t}^{h}$ in (6). As with the smoothing effect, the magnification effect in the many-period analysis amounts to a simple adjustment to one of the variables in the graphical analysis.

\subsection{Other Constraints on the Portfolio Allocation Decision}

Investors may face a variety of other constraints on portfolio allocation decisions because of ownership positions in privately held firms, employment relationships that require certain equity positions, short-sale constraints on risky assets and limitations on borrowing ability. These constraints are easily handled in the two-period setting and often in the many-period setting as well.

Consider investors who must hold long positions in particular risky assets. For example, a small business owner is effectively endowed with a long position in her own business. This long position creates an endowed exposure for the small business owner that is analogous to the endowed exposure implied by a worker's human capital. Thus, we can treat the portfolio allocation decision in the same manner as before by simply redefining income to include profits from the business. Of course, the size, variability and covariance properties of a small business owner's income stream may differ from that of a worker's, but these facts introduce no new conceptual issues. Likewise, a senior executive at a large firm who must hold restricted stock as a condition of employment is also endowed with a particular exposure. Similarly, a pension fund with required holdings in certain firms, sectors or geographic regions is effectively endowed with certain exposures. All of these cases can be handled by simply re-defining the endowed risky income stream in the analysis above.

Short-sale constraints on risky assets are also easily handled in the two-period and many-period settings. Geometrically, and with one risky asset, a short-sale constraint chops off the portion of the feasible set that lies below $\omega_{1}=0$. When a short-sale

$\mathrm{E}_{\mathrm{t}}\left(\mathrm{y}_{\mathrm{t}+\mathrm{i}}^{\mathrm{h}}\right)-\mathrm{E}_{\mathrm{t}-1}\left(\mathrm{y}_{\mathrm{t}+1}^{\mathrm{h}}\right)=\psi_{1}^{\mathrm{h}} \tilde{\eta}_{\mathrm{t}}^{\mathrm{h}}$. This means that $\Psi_{\mathrm{i}}^{\mathrm{h}}=\operatorname{PDV}\left(\left\{\psi_{\mathrm{i}}^{\mathrm{h}}\right\}_{\mathrm{i}=1}^{\mathrm{T}-\mathrm{t}+1}\right)$. 
constraint binds for a particular risky asset, it effectively shuts down the investor's ability to participate in that asset market. Hence, her portfolio allocation can be re-computed after restricting attention to the subset of risky assets for which short-sale constraints do not bind. Because the optimal portfolio has an analytical solution in our model, candidate solutions are easily evaluated to determine which set of markets are effectively open to an investor subject to short-sale constraints.

In practice, short-sale constraints are less likely to bind than they might appear for a couple of reasons. First, higher expected returns on risky assets give every investor a motive to adopt a long position. Only when the correlation between income shocks and asset returns is positive, and the hedging motive is strong enough, will an investor want to adopt a net short position. Second, at the level of a pension fund, for example, short positions taken on behalf of some pension fund beneficiaries can be netted against long positions taken on behalf of other beneficiaries. Thus, a pension fund with a sufficiently diversified pool of beneficiaries can achieve the short positions desired by individual beneficiaries without adopting short positions at the fund level.

Borrowing constraints on the riskless asset are easily handled in the two-period setting. Geometrically, a no-borrowing requirement chops off the portion of the feasible set that lies above the investor's current level of financial assets. If the investor has access to limited borrowing, the constraint on her feasible set is further relaxed. In the manyperiod setting, borrowing constraints on the riskless asset are not as easy to handle. The added complexity arises because the possibility that borrowing constraints bind in the future alters the investor's attitude toward risky assets and the current consumptionsavings choice.

\section{Occupation-Level Income Innovations}

\subsection{Income Data and Selection Criteria}

The Current Population Survey (CPS) randomly samples about 60,000 U.S. households every month. Among other items, the survey inquires about labor income, employment status, hours worked, educational attainment, occupation and demographic characteristics for each household member. The Annual Demographic Files in the March 
CPS contain individual data on these items for the previous calendar year. Using the CPS March files, we estimate occupation-level components of individual annual earnings from 1967 to 1994.

To compute annual earnings, we use CPS data on wage and salary workers in the private and public sectors who were 23 to 59 years old in the earnings year. We exclude unincorporated self-employed persons from the earnings calculations, but we include self-employment and farm income for persons who were mainly wage and salary workers. We restrict the sample to persons who worked at least 500 hours during the year, and we exclude persons who were students or in the military at least part year. ${ }^{18}$ In addition to these individual-level selection criteria, we also impose the occupation-level criteria described below.

The detailed occupational classification schemes in the CPS underwent major changes in 1970 and 1982. Where possible, we constructed a uniform classification scheme from 1967 or 1970 to 1994 based on the occupational descriptions in the CPS documentation and an examination of changes over time in occupational cell counts and mean occupational earnings. We dropped individual-level observations that met any of the following occupation-level selection criteria:

a The occupational group could not be extended back to 1970 or earlier in a consistent manner.

- Self-employed persons account for a large fraction of occupational employment (examples include physicians, dentists, lawyers and farmers).

口 The occupational category is vague (examples include "General Office Supervisors" and "Financial Managers").

- The number of individual-level observations in the occupation had a mean annual cell count less than 100 or a minimum annual cell count less than 50 .

These criteria yield 57 detailed occupational classifications that extend from 1967 or 1970 to 1994 . The occupational selection criteria reduced the number of individual-level observations by about one-half.

\footnotetext{
${ }^{18} \mathrm{We}$ also exclude persons who report an hourly wage less than 75 percent of the federal minimum. We handle top-coded earnings observations in the same manner as Katz and Murphy (1992).
} 
From these 57 occupations, we selected for further analysis 10 occupations with large cell counts and a consistent definition back to 1967. Table 2 lists these occupations and reports summary statistics on cell counts and average annual earnings in 1982 dollars. ${ }^{19}$ As suggested by the table, the 10 occupations range widely in terms of educational requirements and annual labor income.

\subsection{The Occupation-Level Component of Income Innovations}

To extract the occupation-level component of individual earnings shocks, we first fit standard earnings regressions to the individual-level data. We fit separate earnings regressions for each occupation after pooling the data over all available years. For each occupation, we regress real earnings on sex, four educational attainment dummies, a quartic polynomial in age interacted with sex and a full set of occupation-specific year effects. We estimate one set of regressions using annual earnings as the dependent variable and another using log earnings. The log earnings specification is more commonly used by empirical researchers, but the specification in natural units fits more closely with our theoretical model.

Our specification allows the age-earnings profile to vary freely across occupations (and sex) but not to shift over time. Effectively, we treat the occupation's average ageearnings profile over the 1967-1994 period, adjusted for sex and education, as predictable variation in a worker's expected earnings. As implied by the occupation-level earnings specifications described below, we also treat the average occupational earnings growth from 1967 to 1994 (conditional on worker characteristics) as part of expected earnings growth.

Let $\varepsilon_{t}, t=1967,1968, \ldots, 1994$, denote the occupation-year effects estimated in the first-stage earnings regressions. To characterize the stochastic properties of the occupation-level component of individual earnings shocks, we fit simple ARMA models to the first-differenced values of the occupation-year effects. Following earlier work by MaCurdy (1982) using panel data on individuals and by Davis and Willen (2000) using

\footnotetext{
${ }^{19}$ We express earnings in 1982 dollars using the GDP deflator for personal consumption expenditures.
} 
synthetical panel data for demographic groups, we fit second-order moving average processes of the form,

$$
\Delta \varepsilon_{\mathrm{t}}=\alpha+\eta_{\mathrm{t}}+\psi_{1} \eta_{\mathrm{t}-1}+\psi_{2} \eta_{\mathrm{t}-2}
$$

where $\eta_{t}$ denotes the time- $t$ innovation to the occupation-level component of individual earnings shocks. These innovations and their covariance with asset returns are the main focus of the empirical investigation and the applied portfolio analysis in this paper.

It is apparent that our empirical approach ignores selection issues associated with worker mobility across occupational groups and between employment and not working. As a consequence, our estimates of the stochastic process for the occupation-level component of individual earnings may be incorrect even for infra-marginal workers who do not move. A proper treatment of these issues requires long panel data sets. In Davis and Willen (2000), we take the panel requirement seriously by constructing long time series for synthetic persons defined in terms of sex, birth cohort and educational attainment. Alternatively, one can use true panel data sets such as the Panel Survey of Income Dynamics. In practice, the true panel approach has serious limitations imposed by the nature and size of available data sets.

In the absence of panel data sets that contain rich information about hundreds of thousands (better yet, millions) of persons over substantial portions of their life cycles, we think the empirical approach adopted here is a useful one. It can be readily adapted to investigate other components of individual-level earnings shocks that are correlated with observable worker characteristics - e.g., age, job tenure, industry and location. The main requirements for the approach are large cross-sectional individual-level data sets repeated over a number of years. Such data sets are staples of empirical studies in many countries.

\subsection{The Magnitude and Persistence of the Innovations}

The standard deviation of $\eta_{t}$ in equation (7) quantifies the magnitude of innovations to the occupation-level component of individual earnings. The implied magnitude of the shock to the value of human capital depends on the persistence of $\eta$ (a function of $\psi_{1}$ and $\psi_{2}$ ), the risk-free rate of interest, and the number of years remaining until retirement. By combining these elements, we can easily calculate the magnitude of a typical shock to the 
occupation-level component of human capital at a given age. The magnitude of this shock declines with age, because fewer years remain until retirement. ${ }^{20}$

Table 3 and Table 4 display the results of fitting (7) for wages measured in natural units and natural logs, respectively. The tables also report the implied present value multipliers on the occupation-level earnings shocks at ages 30 and 50, assuming a real discount rate of 2.5 percent per year and retirement after age 59 .

To illustrate the calculation of the human capital shock implied by an occupationlevel income innovation, consider the example of Accountants and Auditors at age 30. According to Table 3, the standard deviation of innovations to the occupation-level component of earnings is 1080 dollars, which equals 4.3 percent of annual earnings. At age 30 , the present value multiplier on this innovation is 20.0 , so that the implied impact on human capital amounts to $1080(20.0)=21,600$ dollars. This figure equals 87 percent of the average annual earnings for Accountants and Auditors reported in Table 2. As these calculations show, occupation-level earnings innovations are of modest size, but the implied effects on the present value of lifetime earnings are not.

Occupations differ quite a bit in terms of magnitude and persistence of occupationlevel earnings innovations. The standard deviation of the occupation-level innovations in Table 4 ranges from 2.9 to 6.9 percent of annual earnings. Plumbers have the most volatile occupation-level earnings component in both dollar and percentage terms, while Registered Nurses and Elementary School Teachers have the least volatile.

In most cases, the occupation-level earnings process is less persistent than a random walk. For example, the long-run multiplier on an occupation-level earnings innovation for Accountants and Auditors equals $1+(-.18)+(.11)=.93$, according to the Table 3 . The long run multiplier is much less persistent for Electrical Engineers (.28) and much more persistent for Registered Nurses (1.94). Likewise, the present value multiplier at age 30 is 6.8 for Plumbers and 40.2 for Registered Nurses. These two occupations are outliers in terms of persistence. For the other occupations, the present value multipliers at

\footnotetext{
${ }^{20}$ As we mentioned in Section 2, this simple mechanical effect implies that a worker's endowed exposure to risky financial assets tends to decline with age. It must decline with age if the covariance between labor income innovations and asset returns is nonzero and independent of age. A covariance between labor income innovations and asset returns that rises with age works in the opposite direction of this horizon effect.
} 
age 30 range from 13 to 27 using the natural units wage measure and from 11 to 26 using the log measure.

The last two columns in Table 3 and Table 4 show how the present value multiplier declines between ages 30 and 50, given our assumptions about discounting and retirement. The age-50 multipliers are fairly sensitive to alternative assumptions about retirement age, but the basic point is not. As workers near retirement, earnings innovations have smaller and smaller effects on lifetime resources.

\section{Covariance between Occupation-Level Income Innovations and Asset}

\section{Returns}

\subsection{Covariance with Aggregate Equity Returns}

To investigate the covariance between occupation-level earnings innovations and aggregate equity returns, we regress $\eta_{t}$ from equation (7) on the realized market rate of return during period $t$. Recall that the slope coefficient in an ordinairy least squares (OLS) regression of $y$ on $x$ can be written as $\operatorname{COV}(x, y) / \operatorname{VAR}(x)$. Thus we can use standard regression methods to quantify the covariance between income shocks and equity returns and to test whether the relationship is statistically significant. Other return measures can be introduced as additional regressors to investigate the covariance with multiple assets and to assess the scope for using financial assets to hedge occupationlevel earnings risk. The goodness of fit $\left(R^{2}\right.$ value) in this type of regression has an important economic intepretation: it is the estimated fraction of occupation-level earnings risk that can be hedged by a suitably structured asset portfolio.

In unreported regressions, we find little evidence that occupation-level income innovations and aggregate equity returns are linearly related in annual data from 1968 to 1994. At the 10 percent confidence level, none of the 10 occupations shows a statistically significant relationship between income innovations and returns on the value-weighted market portfolio. $^{21}$ As a check, we also considered the returns on several other broadbased equity indexes: the S\&P 500, the New York Stock Exchange, the Wilshire 5000

\footnotetext{
${ }^{21}$ As reported on Ken French's web site <http://web.mit.edu/kfrench/www/data.library.html.>
} 
and a value-weighted composite of the New York Stock Exchange, American Stock Exchange and NASDAQ. For each measure, the results showed the same pattern of little or no evidence for a relationship between occupation-level income innovations and contemporaneous aggregate equity returns.

This result is quite puzzling from the vantage point of standard economic theories of growth, fluctuations and asset pricing. Equilbrium models that obey standard assetpricing relationships and that embed a conventional specification of the aggregate production technology imply a high positive correlation between aggregate equity returns and shocks to the aggregate value of human capital. ${ }^{22}$ We take note of the puzzle here, but it is not necessary to resolve it to pursue this paper's agenda.

However, the difficulty of reconciling the empirical finding with standard equilibrium models might lead some readers to discount our evidence. Hence, it is worth remarking that other empirical studies find evidence with a similar flavor. For example, under the assumption that labor income growth follows a random walk, Fama and Schwert (1977) find a near-zero correlation between aggregate equity and human capital returns in the United States. Botazzi et al. (1996) report similar results for several countries. Davis, Nalewaik and Willen (2000) find little correlation between aggregate output growth and domestic equity returns in regressions for 14 countries. Davis and Willen (2000) consider the correlation between asset returns and shocks to the value of human capital for synthetic persons defined in terms of sex, birth cohort and educational attainment. The correlations with aggregate U.S. equity returns for these persons are centered near zero, and the goodness-of-fit never exceeds 5 percent of stochastic earnings variation for any group. While they find evidence of statistically significant correlations between equity returns and labor income innovations for some demographic groups, the correlations are

\footnotetext{
${ }^{22}$ By "conventional", we mean a production technology that is approximately Cobb-Douglas over capital and labor. Given a stable Cobb-Douglas technology and a competitive economy, factor income shares are constant over time. Hence, if the same discount rates apply to future capital and labor income, and asset prices reflect fundamentals, the unobserved value of aggregate human capital fluctuates in a manner that is perfectly correlated with the observed value of claims to the aggregate capital stock. Models with these ingredients are standard, but they are hard to reconcile with the emerging body of work the finds low correlations between aggregate equity returns and labor income innovations.
} 
rather modest, typically lying in the inerval from -0.1 to 0.2 . In sum, several studies that consider a variety of countries, time periods and income components find zero or small correlations between aggregate equity returns and the value of human capital.

Empirical work based on larger samples, different components of labor income, different information sets, longer horizons or more refined econometric techniques may yet uncover more powerful relationships between labor income innovations and aggregate equity returns. However, the evidence to date strongly suggests that the "market" portfolio is only weakly correlated with innovations in aggregate and grouplevel measures of labor income. It follows that the market portfolio has modest value as a hedge instrument for the average worker and probably for most occupational and demographic groups as well.

\subsection{Other Asset Return Measures}

We also investigated the covariance between occupation-level income innovations and the returns on long-term government bonds and other assets. Bond returns are significantly correlated with income innovations for a few occupations, as we report below. In most cases, bonds account for a greater fraction of occupation-level income innovations when the returns are measured in nominal terms. Hence, we use nominal bond returns in the regressions below. ${ }^{23}$

We pursued two other ideas for hedging instruments. First, we sought to construct industry equity portfolios that respond sensitively to shocks to the value of human capital in particular occupations. For example, demand shocks in the construction sector induce a positive covariance between equity returns in Construction industries (SICs 15, 16 and 17) and occupation-level income innovations for Electrical Engineers, Electricians and Plumbers. More generally, industry-level demand shocks and factor-neutral technology shocks impart a positive covariance between returns on industry equity and occupationlevel income innovations.

\footnotetext{
${ }^{23}$ We can still specify the first moment of bond returns in real terms for the purposes of portfolio analysis. Data on bond returns are from "U.S. LT Gvt TR" in the "World Capital Market - Fixed" module of the Ibbotson Database.
} 
However, prior reasoning alone cannot determine the sign, let alone the magnitude, of the covariance between industry equity returns and labor income innovations for industry workers. For example, labor-saving technological improvements in construction activity might be good for share holders but bad for the earnings of Electricians and Plumbers. As another example, the deregulation of the trucking industry during the 1970s and early 1980s was bad news for many truck drivers (Rose, 1987) but good news for many trucking firms (Keeler, 1989). The basic point is that factor-biased technology shifts (construction example) and rent shifting between owners and workers (trucking example) impart a negative covariance between industry-level equity returns and occupation-level income innovations.

The bottom line of this discussion is that the usefulness of industry-level equity portfolios as hedging instruments for workers is very much an empirical issue. Furthermore, if the mix of underlying shocks and economic response mechanisms changes over time, the covariance between industry-level equity returns and occupationlevel income innovations is likely to change. The weight of this concern is also largely an empirical issue. No single study can definitively settle these empirical issues, so our results in this regard are best viewed as one installment in a broader empirical inquiry. ${ }^{24}$

We constructed the industry portfolios using firm-level equity returns and market values in the Center for Research in Security Prices (CRSP) database. For each occupation, except Janitors and Cleaners, we identified one or more industries that account for a large fraction of the occupation's employment. In some cases, we had to omit natural SIC counterparts for particular occupations, because CRSP contains no firmlevel observations during part of the sample period. ${ }^{25}$ In the end, we identified the SIC industry groups listed in Table 5 for further analysis. We constructed value-weighted industry returns using firms in the CRSP data, and we updated the firm-level weights

\footnotetext{
${ }^{24}$ Davis and Willen (2000) take a different empirical approach to the same issue. They construct time-varying equity mutual funds for synthetic persons defined in terms of birth cohort, sex and educational attainment. The weights for the equity mutual funds mirror the contemporaneous industry distribution of employment for the workers in the sex-education-cohort group.

${ }^{25}$ For example, SIC 872 (Accounting and Auditing) is a natural industry counterpart for the Accounting and Auditing occupation, but CRSP contains no firm-level observations for SIC 872 during much of the sample.
} 
annually. The rightmost column in Table 5 shows the occupations to which we matched each industry-level return measure.

In another approach to hedging instruments, we considered the covariance between occupation-level income innovations and returns on equity portfolios formed on firm size (market equity value) and the ratio of book-to-market equity value. Fama and French (1993) construct these portfolios, and we use their data on returns. ${ }^{26}$ The Fama-French SMB portfolio pays off the return on a portfolio of firms with small market values minus the return on a portfolio of firms with large market values. The Fama-French HML portfolio pays off the return on a portfolio of "value" stocks with a high ratio of book-tomarket equity minus the return on a portfolio of "growth" stocks with a low ratio of book-to-market equity. The Fama-French portfolios are rebalanced quarterly and adjusted for transactions costs when firms are bought and sold.

Fama and French $(1992,1993,1996)$ show that size and book-to-market factors account for much of the cross-sectional variation in returns on common stocks. Many other asset-pricing studies confirm an important role for these two factors. ${ }^{27}$ The question naturally arises as to what types of risk are being priced by size and book-to-market value. In other words, why do small cap stocks earn a higher average return than large cap stocks? And, why do value stocks earn a higher average return than growth stocks? One possibility is that shocks to the value of human capital covary positively with the size and book-to-market factors. If so, then investors who are exposed to labor income risk will demand a return premium to hold small cap and value stocks. This asset-pricing logic suggests that labor income innovations might be correlated with the returns on the size or book-to-market portfolios. Following this logic, we investigate the covariance between occupation-level income innovations and returns on the SMB and HML portfolios.

\footnotetext{
${ }^{26}$ We obtained the data from Ken French's web site <http://web.mit.edu/kfrench/www/data.library.html.>

${ }^{27}$ See the Fama and French studies for references to related work. Cochrane (2000) reviews the asset-pricing evidence related to size and book-to-market factors and provides references to more recent work.
} 


\subsection{Covariance with other Asset Returns}

We examined bivariate and multivariate regressions of the occupation-level income innovations on returns for bonds, SMB and HML. Bond returns are significantly related to income innovations for a few occupations, and HML returns add modestly to the goodness of fit in regressions for Truck Drivers. However, only the SMB return exhibits a statistically significant relationship to the income innovations for most occupations.

Table 6 displays the bivariate regression results for SMB. ${ }^{28}$ The table shows that the SMB portfolio accounts for 10 percent or more of income variation for about half the occupations. For several occupations, the regression results imply a fairly large positive correlation between income innovations and the SMB return. The correlation for Accountants and Auditors, for example, is $\sqrt{ } .14=.37$.

Drawing on Table 3, Table 5 and Table 6, we can calculate the implied covariance between asset returns and innovations to the value of human capital for Accountants and Auditors as follows. The standard deviation of annual returns on SMB is 15.5 percent. So, a realized return on SMB that is one standard deviation above its mean is associated with an innovation in the value of human capital equal to $(15.5)(-25.2)(20.0)=-7,812$ dollars.

In unreported results, we reran the regressions in Table 6 including the return on the market portfolio. The market return is never significant at the 10 percent level in these regressions. The SMB coefficients and the corresponding $t$-statistics are typically somewhat larger when we include the market portfolio. We also examined regressions on the Fama-French SMB "factor", which differs from the SMB "portfolio" in that it includes no adjustment for the costs of portfolio rebalancing. These unreported results were similar to Table 6 but showed better fits for a few occupations. In the only dramatic difference, the $R^{2}$ value for Electrical Engineers is twice as large for the SMB factor as for the SMB portfolio.

The results in Table 6 suggest that the size portfolio offers some scope for hedging occupation-level income risk, as suggested by the asset-pricing logic outlined above.

\footnotetext{
${ }^{28}$ When we allow the small cap and big cap portfolios to enter the regressions separately, they do so with opposite signs and roughly equal magnitudes; likewise, for the growth and value portfolios.
} 
However, the pattern of results in Table 6 runs directly counter to our original motivation for investigating the SMB portfolio. Most of the slope coefficients in Table 6, and all of the statistically significant ones, imply that the relative return on small cap stocks covaries negatively with occupation-level income innovations. Thus, investors who are exposed to labor income risk should be willing to hold small cap equities at a return discount relative to large cap equities. In fact, the average return on small cap stocks is higher. ${ }^{29}$ So, while the findings in Table 6 are useful for portfolio allocation purposes, they heighten rather than resolve asset-pricing puzzles related to the return premium on small cap stocks.

Table 7 and Table 8 show regression results for the best-fitting set of asset return measures. We selected the best-fitting set based on the adjusted $R^{2}$ value in regressions on SMB, HML, bonds and the industry portfolios listed in Table 5. Four of the industry meausures raised the adjusted $R^{2}$ value in at least one regression. ${ }^{30}$ None of the assets we considered had explanatory power for Auto Mechanics.

Several results in Table 7 and Table 8 merit some attention. First, the results involving the SMB portfolio are typically strengthened by the inclusion of other assets. Second, the best-fitting set of asset returns accounts for 20 percent or more of occupation-level income risk for several occupations. Third, the covariance structure between income innovations and asset returns differs considerably across occupations. SMB is related to income innovations in most, but not all, occupations. Bonds are significantly related to income innovations in four occupations, but the sign of the relationship for Registered Nurses differs from the other occupations. Occupation-level income innovations for Auto Mechanics are unrelated to any of the asset returns we tried. Fourth, the industry equity portfolios are part of the best-fitting set of asset returns for

\footnotetext{
${ }^{29}$ Table 5 shows a very modest return premium on small cap stocks during our sample period. As others have observed, the realized premium on small cap stocks has declined in recent decades. The average annual value of the Fama-French SMB portfolio return was about eight percentage points from 1964 to 1980 and minus four percentage points from 1981 to 1994.

${ }^{30}$ Aggregate equity returns are not statistically significant when added to the regression specifications shown in Table 7 and Table 8
} 
about half of the occupations, although $t$-statistics for a test of the null hypothesis of no relationship to income innovations are usually below 2 .

In summary, the regression results identify one or more assets for each occupation (except Auto Mechanics) that appear to provide some scope for hedging the occupationlevel income innovations and shocks to the value of human capital for workers in those occupations. In the next section, we use these empirical results to construct optimal portfolios of risky assets according to the theory developed in Sections 2 and 3.

\section{Life Cycle Portfolio Choice with Risky Labor Income: Some Examples}

We now implement the solution to the life cycle portfolio problem with risky labor income. We draw upon the empirical work in Sections 3 and 4 to characterize the magnitude, persistence and covariance properties of labor income shocks.

\subsection{Portfolio Allocations under Two-Fund Separation}

Table 9 shows optimal portfolio allocations when asset returns and labor income are uncorrelated. The table considers three risky assets - the market, size and value portfolios - and uses a real risk-free return of 3.5 percent per year. We do not impose short-sale contraints on risky asset holdings or restrictions on borrowing at the risk-free rate. Since two-fund separation holds under these conditions, every investor has the same risky asset portfolio shares, as shown in the top row. These shares depend on the joint return distribution for the three assets, which we fit to the first two sample moments in the data.

The table also displays optimal risky asset holdings at ages 40 and 60 for two occupations under various assumptions about relative risk aversion and expected returns. Given the coefficient of relative risk aversion (CRRA), we calculate the corresponding level of absolute risk aversion as

$$
A=\frac{C R R A}{\sum_{a=23}^{59} y_{a} /(75-22)}
$$

The denominator in this expression is a crude proxy for permanent income based on labor earnings from ages 23 to 59 and assuming that age 75 is the last year of life. The dynamic absolute risk aversion level that governs risky asset demand at each age equals 
the product of $A$ and the marginal propensity to consume out of wealth, as discussed in Section 3.

This simple procedure neglects some issues that arise in a more careful calibration of the risk aversion coefficients (and their variation over the life cycle). First, for exponential utility, Davis and Willen (2000) show that consumption is proportional to a broad measure of wealth that includes the value of human capital, the discounted value of expected future excess returns on risky asset holdings and a downward adjustment for consumption uncertainty that reflects precautionary behavior. The above procedure for calculating $A$ treats human capital in a crude way and ignores the other components of the broad wealth measure. Second, changes in wealth and background risk over the life cycle influence the demand for risky assets when preferences do not have the exponential form. For example, preferences with constant relative risk aversion imply that absolute risk aversion falls with wealth and rises with background risk. The effects of expected life cycle variaton in wealth and background risk can be captured in an exponential framework by introducing life cycle variation in $A$. Third, mortality risk rises with age, so that an investor's effective time discount rate also rises with age. We set these issues aside here, because they are sufficiently involved as to merit an extended treatment in a separate paper. ${ }^{31}$

Table 9 shows that an Electrical Engineer with relative risk aversion of 3 should, according to the theory, hold a 1.03 million dollar portfolio of risky assets. The portfolio consists of a 257 thousand dollar short position in SMB and long positions in HML and the market portfolio. The optimal risky positions are smaller if we consider an otherwise identical investor who is 60 years old, or one who has relative risk aversion of 5. Optimal holdings are also about 40 percent smaller for a Secondary School Teacher, because her permanent income is about 40 percent smaller. In line with the two-fund separation principle, none of these changes alter the optimal portfolio shares.

\footnotetext{
${ }^{31}$ An interesting research question is how to best approximate the savings and portfolio choice behavior of a consumer-investor with constant relative risk aversion by suitably specifying the life cycle path for $A$ in a framework with exponential utility. A related question is how the best exponential approximation compares to approximate analytical solutions based on $\log$ linearization methods and to numerical approximation methods.
} 
In all of these cases, the optimal holdings are quite large relative to casual and systematic evidence regarding actual holdings - 40-year old Electrical Engineers who hold million dollar equity portfolios are not the norm. One important factor behind this gap between theory and evidence is the high returns on U.S. equities over the last century. Since many analysts believe that these high returns are unlikely to hold in the future, the last row in each panel of Table 9 shows the optimal allocations for expected returns on risky assets that are only half as large as the corresponding sample means. Investment positions drop by half as well, but the optimal allocations remain quite large compared to observed holdings for the typical person. This portfolio puzzle seems to have escaped attention in previous research because of the strong proclivity to focus on portfolio shares and to disregard theoretical implications for the level of risky asset holdings. $^{32}$

We believe that the resolution of this puzzle rests at least partly on the opportunity cost of investor funds. In computing the portfolio allocations in Table 9, we allow investors to borrow unlimited amounts at the risk-free interest rate. If investors must instead borrow at an interest rate that approximates the expected return on risky assets, then the optimal risky asset position is approximately zero when asset returns and labor income are uncorrelated. Since many (potential) investors face an opportunity cost of funds at least as great as the expected return on equities, it is unsurprising that half or more of all housholds have little or no holdings of risky financial assets.

\subsection{Endowed Exposure and the Breakdown of Two-Fund Separation}

Non-zero covariances between asset returns and labor income cause two-fund separation to break down in a particular way. To illustrate this point, Table 10 shows optimal allocations for seven occupations when we account for covariance with labor income shocks. Recall from Section 1 that optimal holdings in the zero-correlation case, "desired exposure", depend only on absolute risk aversion and asset returns. "Endowed

\footnotetext{
${ }^{32}$ Davis, Nalewaik and Willen (2000) discuss this portfolio puzzle in connection with the gains to international trade in risky financial assets.
} 
exposure" gives the risky asset position implicit in the covariance between asset returns and the worker-investor's labor income.

The regression results in Section 4 show that most of our occupational groups have an endowed exposure to the SMB portfolio. As we explained in Section 2, the endowed exposure reflects the persistence of labor income innovations and their covariance with asset returns. So, while Electrical Engineers have much greater covariance of income innovations with SMB returns than Secondary School Teachers, income innovations are more pesistent for the latter and their endowed exposure is greater.

To calculate an investor's optimal portfolio, we simply subtract endowed exposure from desired exposure. Since endowed exposure is not proportional to desired exposure, two-fund separation fails. Other things equal, the bigger the endowed exposure the bigger the departure from the two-fund separation principle.

Table 11 illustrates this breakdown by showing optimal portfolio shares under different assumptions about risk aversion and excess returns for each occupation that has a non-zero covariance with one or more of the assets. The base case uses sample average excess returns and a relative risk aversion of 3. Given these assumptions, the departures from two-fund separation are modest. For example, the optimal shares for Electrical Engineers never differ from the zero-covariance optimum by more than three percentage points. For Secondary School Teachers, the traditional zero-covariance portfolio understates SMB holdings by nine percentage points.

Because these effects are small, a portfolio manager might be forgiven for ignoring them. However, if one believes that high equity returns are an aberration, or that expected returns have declined in recent years, then the effects of covariance on optimal portfolio shares become more important. As an example, the second line for each occupation in Table 11 shows optimal portfolio shares when we set excess returns to one-half their sample averages. Recall that this change has no impact on the optimal shares when twofund separation holds. In particular, the optimal SMB share is -25 percent under two-fund separation, regardless of whether we scale down excess returns. This invariance result fails when we take covariance into account.

As an example, the optimal SMB portfolio shares for Secondary School Teachers is +2 percent when excess returns are half their sample values and relative risk aversion is 
5. To understand this result, recall that the level of excess returns has no effect on "endowed exposure". So, as we reduce excess returns and, hence, desired exposure, the relative size of endowed exposure goes up.

Higher risk aversion has the same effect, and for much the same reason. Greater risk aversion lowers desired exposure but does not affect endowed exposure. The last line in each panel of Table 11 shows optimal portfolio shares for the case of high risk aversion and low excess returns. In this case, the optimal portfolio shares sometimes deviate substantially from the two-fund separation principle. Based on traditional mean-variance analysis, a portfolio advisor would recommend a 25 percent short position in SMB. In contrast, the optimal position for Secondary School Teachers is a 17 percent long position in a plausible case that accounts for covariance betwen asset returns and labor income.

\subsection{Life Cycle Variation in Endowed Exposure}

Table 12 shows endowed exposure to the occupation-specific assets at different stages of the life cycle. Given an age-invariant covariance between labor income innovations and asset returns, the endowed exposure declines monotonically with age as the worker-investor draws down her human capital. This result follows immediately when the covariance is age invariant. ${ }^{33}$ The rate of decline in endowed exposure is the same for the other risky assets.

As we discussed earlier, endowed exposure depends both on covariance and the present value multiplier. Although the covariance with the Health asset for Registered Nurses is much lower than the covariance with the Build asset for Electrical Engineers, the present value multiplier on occupation-level income innovations is five times bigger for Registered Nurses. As a result, the endowed exposures to the industry-level assets for these two occupations are fairly similar early on in the life cycle.

A final issue involves life cycle variation in the extent of departures from two-fund separation. Other things equal, a declining path of endowed exposure leads to ever

\footnotetext{
${ }^{33}$ Davis and Willen (2000) allow this covariance to vary smoothly with age in their empirical work but find only modest life cycle variation for demographic groups defined in terms of sex, education and birth cohort. Given their findings, and since their empirical design is better suited for uncovering age effects of this sort, we imposed an age-invariant covariance structure in this paper.
} 
smaller departures from two-fund separation as a consumer-worker ages. However, income smoothing capacity and "dynamic risk aversion" also decline with age, which creates a countervailing force. In particular, greater risk aversion intensifies the effect of covariance on optimal portfolio shares, as we showed above. So, for any given level of endowed exposure, the departure from two-fund separation is bigger for an older workerinvestor.

\section{Concluding Remarks}

When labor income (or proprietary business income) and asset returns are correlated, investors are implicitly endowed with certain exposures to risky financial assets. These endowed exposures have important effects on optimal portfolio allocation.

We develop a simple graphical approach to portfolio choice over the life cycle that accounts for an investor's endowed exposure. Our graphical approach easily handles risky labor income, multiple risky assets, many periods and several determinants of portfolio choice over the life cycle. As an added virtue, the chief empirical inputs into the framework are easily estimated using standard statistical procedures.

The two-fund separation principle that governs optimal portfolio choice in a traditional mean-variance setting breaks down when investors have endowed exposures to risky assets. In simple terms, an investor's optimal portfolio can be calculated as the difference between her desired exposure to risky assets and her endowed exposure. Because investors typically differ in their endowed exposures, they also differ in their optimal portfolio allocations (levels and shares), even when they have the same tolerance for risk and the same beliefs about asset returns.

The emprical approach to endowed exposure in this paper relies on repeated cross sections to extract occupation-level components of individual income innovations. Using annual data from 1968 to 1994, we find little evidence that occupation-level income innovations are correlated with aggregate equity returns. This finding and similar findings in other work present something of a puzzle for standard equilibrium models of fluctuations, growth and asset pricing. Given rational asset pricing behavior, frictionless financial markets and standard specifications of the aggregate production technology, dynamic equilibrium models imply a high correlation between aggregate equity returns 
and the value of human capital. That implication finds little support in our empirical results.

We do find evidence that several other asset return measures are correlated with occupation-level income innovations. The returns on portfolios formed on firm size (market capitalization) are correlated with occupation-level income innovations for about half the occupations we consider. In a few occupations, income innovations are correlated with returns on long term bonds. In several instances, industry-level equity returns are correlated with the occupation-level income innovations of the workers in those industries. Both a priori reasoning and our empirical results suggest that industry-level equity returns can covary negatively or positively with labor income innovations for industry workers. It follows that the optimal hedge portfolio for occupation-specific and industry-specific components of risky labor income cannot be discerned without intensive empirical study.

When we apply the estimated covariances to our portfolio choice framework, we find sizable departures from the two-fund separation principle for plausible assumptions about expected asset returns and investor risk aversion. It is likely that future empirical research will more fully uncover the covariance structure between labor income and asset returns. If so, then the gap between optimal portfolio allocations and the uniform portfolio shares implied by the two-fund separation principle will also be larger.

\section{Mathematical Appendix}

For expositional convenience, the discussion in the text presumes that the risk-free interest rate equals the subjective discount rate equal. In the brief derivation of equations (1) and (2) that follow, we consider the more general case where the subjective discount factor $\delta^{h}$ is not necessarily equal to the reciprocal of the gross return on the riskless asset.

In the two-period mdoel, the single-period budget constraints are $c_{0}^{h}=\mathrm{y}_{0}^{h}-\omega_{0}^{h}-\omega_{1}^{h}$ and $\tilde{c}_{1}^{h}=\tilde{y}_{1}^{h}+R_{0} \omega_{0}^{h}+\tilde{R}_{1} \omega_{1}^{h}$. Combining these two equations to 
eliminate $\omega_{0}^{h}$ gives the intertemporal budget constraint:

$$
\mathrm{c}_{0}^{\mathrm{h}}+\frac{1}{\mathrm{R}_{0}} \tilde{\mathrm{c}}_{1}^{\mathrm{h}}=\mathrm{y}_{0}^{\mathrm{h}}+\frac{1}{\mathrm{R}_{0}} \tilde{\mathrm{y}}_{1}^{\mathrm{h}}+\frac{1}{\mathrm{R}_{0}}\left(\tilde{\mathrm{R}}_{1}-\mathrm{R}_{0}\right) \omega_{1}^{\mathrm{h}}
$$

Taking expectations gives equation (1) in the main text.

By definition,

$$
U^{h}\left(c_{0}^{h}, \tilde{c}_{1}^{h}\right)=-\frac{1}{A^{h}}\left[\exp \left(-A^{h} c_{0}^{h}\right)+\delta^{h} E \exp \left(-A^{h} \tilde{c}_{1}^{h}\right)\right] .
$$

The first-order condition of the optimization problem with respect to the riskless asset is

$$
\exp \left(-A^{h} c_{0}^{h}\right)=\delta^{h} R_{0} E\left(\exp \left(-A^{h} \tilde{c}_{1}^{h}\right)\right)
$$

Substituting (A3) into (A2) characterizes utility entirely in terms of period-0 consumption:

$$
U^{h}\left(c_{0}^{h}, \tilde{c}_{1}^{h}\right)=-\frac{1}{A^{h}}\left(1+\frac{1}{R_{0}}\right) \exp \left(-A^{h} c_{0}^{h}\right) .
$$

Since $\tilde{c}_{1}^{h}$ is the sum of normal random variables, it is also normal and we have

$$
E\left(\exp \left(-A^{h} \tilde{c}_{1}^{h}\right)\right)=\exp \left(-A^{h} E\left(\tilde{c}_{1}^{h}\right)+\frac{1}{2} \operatorname{var}\left(A^{h} \tilde{c}_{1}^{h}\right)\right) .
$$

Taking logs of (A3) and substituting in (A5) yields

$$
E\left(\tilde{c}_{1}^{h}\right)=c_{0}^{h}+\frac{1}{2} A^{h} \operatorname{var}\left(\tilde{c}_{1}^{h}\right)+\ln \delta^{h} R_{0} .
$$

Substituting (A6) into (1) gives:

$$
\left(1+\frac{1}{R_{0}}\right) c_{0}^{h}=W^{h}-\frac{1}{2} A^{h} \operatorname{var}\left(\tilde{c}_{1}^{h}\right)-\ln \delta^{h} R_{0}
$$

Substituting (A7) into (A4) and imposing $\ln \delta^{h} R_{0}=0$ gives equation (2) in the text.

The many-period version follows by backward induction. The key insight is that since first-period consumption is affine in $W^{h}$, the distribution of consumption conditional on information in earlier periods is still normal and the above argument can be used with small adjustment. For details, see Davis and Willen (2000). 


\section{References}

Ameriks, John and Stephen P. Zeldes, 2000. "How Do Household Portfolio Shares Vary with Age?" working paper, Columbia University, May 22.

Baxter, Marianne and Urban J. Jermann, 1997, “The International Diversification Puzzle Is Worse than You Think," American Economic Review, 87, number 1 (March) 170-180.

Bodie, Zvi, Robert C. Merton and William F. Samuelson, 1992. "Labor supply flexibility and portfolio choice in a life cycle model." Journal of Economic Dynamics and Control, 16, 427-449.

Botazzi, Laura, Paolo Pesenti and Eric van Wincoop, 1996. "Wages, profits and the international portfolio puzzle." European Economic Review, 40(2), 219-254.

Campbell, John Y., João F. Gomes, Francisco J. Gomes and Pascal J. Maenhout, 1999. "Investing Retirement Wealth: A Life cycle Model," NBER Working Paper Number 7029.

Canner, Niko, N. Gregory Mankiw and David N. Weil, 1998. "An Asset Allocation Puzzle," American Economic Review, 87, no. 1 (March), 181-191.

Cocco, Joao, Francisco Gomes and Pascal Maenhout, 1999. "Consumption and portfolio choice over the life cycle." Working paper, Harvard University.

Cochrane, John H., 2000. "New Facts in Finance," Federal Reserve Bank of Chicago Economic Perspectives.

Davis, Steven and Paul Willen, 2000. "Using financial assets to hedge labor income risks: Estimating the benefits." Working paper: University of Chicago and Princeton.

Davis, Steven, Jeremy Nalewaik and Paul Willen, 2000. "On the Gains to International Trade in Risky Financial Assets," NBER Working Paper 7796.

Davis, Steven, Wendy Edelberg, Jeremy Nalewaik and Paul Willen, 2000. "The Opportunity Cost of Funds and Cross-Sectional Variation in Risky Asset Holdings" work in progress, University of Chicago Graduate School of Business.

Dréze, Jacques H. and Franco Modigliani, 1972. "Consumption Decisions Under Uncertainty," Journal of Economic Theory, 5, 308-335. 
Fama, Eugene F. and Kenneth F. French, 1992. "The Cross-Section of Expected Stock Returns," Journal of Finance, 47, no. 2 (June), 427-465.

Fama, Eugene F. and Kenneth F. French, 1993. "Common Risk Factors in the Returns on Stocks and Bonds," Journal of Financial Economics, 33, 3-56.

Fama, Eugene F. and Kenneth F. French, 1996. "Multifactor Explanations of AssetPricing Anomalies," Journal of Finance, 51, no. 1 (March) 55-84.

Fama, Eugene F. and William Schwert, 1977. "Human Capital and Capital Market Equilibrium," Journal of Financial Economics, 4, no. 1 (January), 95-125.

Haliassos, Michael and Alexander Michaelides, 1999. "Portfolio choice and liquidity constraints." Working paper: University of Cyprus.

Heaton, John and Deborah Lucas, 1997. "Market frictions, savings behavior and portfolio choice." Macroeconomic Dynamics 1(1), 76-101.

Heaton, John and Deborah Lucas, 2000. "Portfolio choice and asset prices: The importance of entrepreneurial risk," Journal of Finance, (June).

Ingersoll, Jonathan E., Jr., 1987. Theory of Financial Decision Making. Totowa, New Jersey: Rowman \& Littlefield.

Jagannathan, R. and Narayana R. Kocherlakota, 1996. "Why Should Older People Invest Less in Stocks than Younger People?" Federal Reserve Bank of Minneapolis Quarterly Review, 20(3), 11-23.

Katz, Lawrence F. and Kevin M. Murphy, 1992. "Changes in Relative Wages, 1963-87: Supply and Demand Factors," Quarterly Journal of Economics, 107, 35-78.

Keeler, Theodore E., 1989. "Deregulation and Scale Economies in the U.S. Trucking Industry," Journal of Law and Economics, 32 229-255.

MaCurdy, Thomas E., 1982. "The Use of Time Series Processes to Model the Error Structure of Earnings in a Longitudinal Data Analysis," Journal of Econometrics, $18,83-114$.

Rose, Nancy L., 1987. "Labor Rent Sharing and Regulation: Evidence from the Trucking Industry," Journal of Political Economy, 95, 1146-1178.

Samuelson, Paul A., 1969. "Lifetime Portfolio Selection by Dynamic Stochastic Programming," Review of Economics and Statistics, 51, 239-243. 
Viceira, Luis, 1998. "Optimal portfolio choice for long-horizon investors with nontradable labor income." Working paper: Harvard University.

Willen, Paul, 1999. "Welfare, Financial Innovation and Self Insurance in Dynamic Incomplete Market Models," Princeton University, May. 
Table 1: Correlation between simple and residual assets.

\begin{tabular}{lcc}
\hline $\operatorname{corr}\left(\tilde{R}_{1}, \tilde{R}_{2}\right)$ & \multicolumn{2}{c}{$\operatorname{corr}\left(\tilde{y}_{1}, \tilde{R}_{2}\right)$} \\
\hline & Simple & Residual \\
\hline 0.80 & 0.25 & -0.42 \\
0.70 & 0.25 & -0.20 \\
0.60 & 0.25 & -0.08 \\
0.50 & 0.25 & 0.00 \\
0.40 & 0.25 & 0.06 \\
0.30 & 0.25 & 0.11 \\
0.20 & 0.25 & 0.16 \\
0.10 & 0.25 & 0.20 \\
0.00 & 0.25 & 0.25 \\
\hline \hline
\end{tabular}

Source: Authors' calculations. 
Table 2: Occupational Classifications and Summary Statistics

\begin{tabular}{llllll}
\hline Occupational Description & $\begin{array}{l}\text { 1980 Standard } \\
\text { Occupational } \\
\text { Classification }\end{array}$ & $\begin{array}{l}\text { Sample } \\
\text { Period }\end{array}$ & $\begin{array}{l}\text { Mean } \\
\text { Cell } \\
\text { Count }\end{array}$ & $\begin{array}{l}\text { Minimum } \\
\text { Cell } \\
\text { Count }\end{array}$ & $\begin{array}{l}\text { Average } \\
\text { Earnings in } \\
\text { 1982 Dollars }\end{array}$ \\
\hline \hline Accountants and Auditors & 23 & $1967-94$ & 542 & 327 & 24,881 \\
Electrical Engineers & 55 & $1967-94$ & 246 & 150 & 33,923 \\
Registered Nurses & 95 & $1967-94$ & 704 & 392 & 17,823 \\
Teachers, Elementary & 156 & $1967-94$ & 842 & 679 & 18,325 \\
Teachers, Secondary & 157 & $1967-94$ & 733 & 487 & 20,886 \\
Janitors and Cleaners & 453 & $1967-94$ & 805 & 336 & 11,846 \\
Auto Mechanics & 505 & $1967-94$ & 389 & 306 & 17,675 \\
Electricians & 575 & $1967-94$ & 325 & 267 & 23,646 \\
Plumbers & 585 & $1967-94$ & 220 & 168 & 22,437 \\
Truck Drivers & 804,805 & $1967-94$ & 1079 & 744 & 18,665 \\
\hline \hline
\end{tabular}

Source: Authors' tabulations from the Annual Demographic Files of the March Current population Survey using the selection criteria described in the text.

Note: The average earnings figure is the simple mean from 1967-1994 of the unweighted mean annual earnings among persons who satisfy the selection criteria. 
Table 3: Stochastic Process for Occupational Component of Individual Earnings, Second-Order Moving Average Fit to First Differences, 1968-1994

\begin{tabular}{|c|c|c|c|c|c|c|c|}
\hline \multirow[t]{2}{*}{ Occupational Description } & \multirow[t]{2}{*}{$\begin{array}{l}\text { Intercept X } \\
100\end{array}$} & \multirow[t]{2}{*}{$\begin{array}{l}\text { MA(1) } \\
\text { Coefficient }\end{array}$} & \multirow[t]{2}{*}{$\begin{array}{l}\mathrm{MA}(2) \\
\text { Coefficient }\end{array}$} & \multirow{2}{*}{$\begin{array}{l}\text { Root Mean } \\
\text { Squared } \\
\text { Error X } 100\end{array}$} & \multirow[t]{2}{*}{$\begin{array}{l}\text { R-Squared } \\
\text { Value }\end{array}$} & \multicolumn{2}{|c|}{$\begin{array}{l}\text { Present Value Multiplier } \\
\text { at: }\end{array}$} \\
\hline & & & & & & Age 30 & Age 50 \\
\hline Accountants and Auditors & 65 & -0.18 & 0.11 & 1080 & 0.04 & 20.0 & 8.3 \\
\hline Electrical Engineers & 67 & -0.58 & -0.14 & 1283 & 0.22 & 6.8 & 3.4 \\
\hline Registered Nurses & 246 & 0.30 & 0.64 & 446 & 0.25 & 40.2 & 15.9 \\
\hline $\begin{array}{l}\text { Elementary School } \\
\text { Teachers }\end{array}$ & 85 & -0.08 & 0.38 & 525 & 0.10 & 27.2 & 11.0 \\
\hline $\begin{array}{l}\text { Secondary School } \\
\text { Teachers }\end{array}$ & 15 & 0.08 & -0.02 & 637 & 0.00 & 22.5 & 9.4 \\
\hline Janitors and Cleaners & -36 & -0.35 & -0.06 & 583 & 0.09 & 13.3 & 5.8 \\
\hline Auto Mechanics & -79 & -0.02 & -0.12 & 714 & 0.01 & 18.9 & 8.0 \\
\hline Electricians & -119 & 0.17 & -0.60 & 951 & 0.16 & 13.2 & 6.1 \\
\hline Plumbers & -150 & -0.22 & -0.22 & 1453 & 0.06 & 12.8 & 5.7 \\
\hline Truck Drivers & -35 & 0.14 & -0.30 & 790 & 0.06 & 18.5 & 8.0 \\
\hline
\end{tabular}

Notes:

For each occupation, a second-order moving average process is fit to the occupational component of individual annual earnings in 1982 dollars. The moving average process is estimated by (conditional) nonlinear least squares.

See the text for an explanation of how the occupational component of individual earnings is identified.

The present value multipliers are computed using a real discount rate of 2.5 percent per year and assuming retirement after age 59 .

Source: Authors' calculations, CPS data. 
Table 4: Stochastic Process for Occupational Component of Individual Log Earnings, Second-Order Moving Average Fit to First Differences, 1968-1994

\begin{tabular}{|c|c|c|c|c|c|c|c|}
\hline \multirow[t]{2}{*}{ Occupational Description } & \multirow[t]{2}{*}{$\begin{array}{l}\text { Intercept X } \\
100\end{array}$} & \multirow[t]{2}{*}{$\begin{array}{l}\text { MA(1) } \\
\text { Coefficient }\end{array}$} & \multirow[t]{2}{*}{$\begin{array}{l}\text { MA(2) } \\
\text { Coefficient }\end{array}$} & \multirow{2}{*}{$\begin{array}{l}\text { Root Mean } \\
\text { Squared } \\
\text { Error X } 100 \\
\end{array}$} & \multirow[t]{2}{*}{$\begin{array}{l}\text { R-Squared } \\
\text { Value }\end{array}$} & \multicolumn{2}{|c|}{$\begin{array}{l}\text { Present Value Multiplier } \\
\text { at: }\end{array}$} \\
\hline & & & & & & Age 30 & Age 50 \\
\hline Accountants and Auditors & 0.0 & -0.26 & -0.04 & 4.3 & 0.06 & 15.3 & 6.6 \\
\hline Electrical Engineers & 0.2 & -0.67 & -0.12 & 3.9 & 0.26 & 5.5 & 2.8 \\
\hline Registered Nurses & 1.6 & 0.26 & 0.45 & 3.3 & 0.15 & 35.5 & 14.2 \\
\hline $\begin{array}{l}\text { Elementary School } \\
\text { Teachers }\end{array}$ & 0.2 & -0.09 & 0.32 & 2.9 & 0.05 & 26.0 & 10.6 \\
\hline $\begin{array}{l}\text { Secondary School } \\
\text { Teachers }\end{array}$ & 0.0 & -0.02 & 0.01 & 3.4 & 0.00 & 21.4 & 8.9 \\
\hline Janitors and Cleaners & -0.6 & -0.38 & -0.07 & 4.4 & 0.12 & 12.2 & 5.4 \\
\hline Auto Mechanics & -0.7 & -0.02 & 0.00 & 4.3 & 0.00 & 21.0 & 8.8 \\
\hline Electricians & -0.8 & 0.17 & -0.63 & 3.8 & 0.25 & 12.7 & 5.9 \\
\hline Plumbers & -1.1 & -0.32 & -0.18 & 6.9 & 0.09 & 11.4 & 5.2 \\
\hline Truck Drivers & -0.4 & 0.00 & -0.15 & 4.3 & 0.01 & 18.7 & 8.0 \\
\hline
\end{tabular}

See notes and source for Table 2. 
Table 5: Asset Return Measures, Definitions and Summary Statistics

\begin{tabular}{|c|c|c|c|c|}
\hline $\begin{array}{l}\text { Variable } \\
\text { Name }\end{array}$ & Short Description & $\begin{array}{l}\text { Mean Annual } \\
\text { Return in } \\
\text { Percent, 1968- } \\
1994\end{array}$ & $\begin{array}{l}\text { Standard } \\
\text { Deviation } \\
\text { of Annual } \\
\text { Returns } \\
\end{array}$ & $\begin{array}{l}\text { Occupation } \\
\text { Match }\end{array}$ \\
\hline$\overline{\text { SMB }}$ & $\begin{array}{l}\text { Fama-French Size } \\
\text { Portfolio, Small-Big }\end{array}$ & 0.2 & $\begin{array}{l}15.5 \\
\end{array}$ & All \\
\hline HML & $\begin{array}{l}\text { Fama-French Book-to- } \\
\text { Market Portfolio, Value - } \\
\text { Growth Stocks }\end{array}$ & 5.9 & 12.9 & All \\
\hline Bonds & $\begin{array}{l}\text { Nominal Return on 10- } \\
\text { Year Constant Maturity } \\
\text { U.S. Government Bonds }\end{array}$ & 8.5 & 10.1 & All \\
\hline Autos & $\begin{array}{l}\text { Real Return on SIC } 371 \\
\text { (Auto Mfg.) }\end{array}$ & 6.4 & 25.0 & Auto Mechanics \\
\hline Elmach & $\begin{array}{l}\text { Real Return on SIC } 36 \\
\text { (Electrical Machinery } \\
\text { Manufacturing) }\end{array}$ & 5.8 & 21.4 & $\begin{array}{l}\text { Electrical } \\
\text { Engineers }\end{array}$ \\
\hline Build & $\begin{array}{l}\text { Real Return on SICs 15, } \\
16,17 \text { (Construction) }\end{array}$ & 3.2 & 27.8 & $\begin{array}{l}\text { Elec. Engs., } \\
\text { Electricians, } \\
\text { Plumbers }\end{array}$ \\
\hline Freight & $\begin{array}{l}\text { Real Return on SIC } 42 \\
\text { and } 472, \text { ex. } 4725 \\
\text { (Freight Transport by } \\
\text { Road) }\end{array}$ & 6.4 & 27.8 & Truck Drivers \\
\hline Technical & $\begin{array}{l}\text { Real Return on SICs } 871 \\
\text { and } 7336 \text { (Engineering, } \\
\text { Architectural and } \\
\text { Technical Services) }\end{array}$ & 8.1 & 31.9 & $\begin{array}{l}\text { Electrical } \\
\text { Engineers }\end{array}$ \\
\hline Education & $\begin{array}{l}\text { Real Return on SICs } 82 \text {, } \\
\text { ex. 823, and } 833 \\
\text { (Education Services) }\end{array}$ & 6.4 & 37.1 & $\begin{array}{l}\text { Elementary and } \\
\text { Secondary } \\
\text { Teachers }\end{array}$ \\
\hline Health & $\begin{array}{l}\text { Real Return on SIC } 80 \\
\text { (Medical, Dental and } \\
\text { Health Services) }\end{array}$ & 12.8 & 37.1 & $\begin{array}{l}\text { Registered } \\
\text { Nurses }\end{array}$ \\
\hline Utility & $\begin{array}{l}\text { Real Return on SICs } 46 \\
\text { and } 49 \text {, ex. } 495 \\
\text { (Electricity, Gas, Steam, } \\
\text { Water Works) }\end{array}$ & 5.4 & 15.8 & $\begin{array}{l}\text { Electrical } \\
\text { Engineers, } \\
\text { Electricians, } \\
\text { Plumbers } \\
\end{array}$ \\
\hline Finance & $\begin{array}{l}\text { Real Return on SICs } 62 \\
\text { and } 67 \text { (Investment } \\
\text { Banking, Securities } \\
\text { Markets, Exchanges) }\end{array}$ & 7.9 & 19.8 & $\begin{array}{l}\text { Accountants and } \\
\text { Auditors }\end{array}$ \\
\hline
\end{tabular}


Notes and Sources:

(1) Returns data for the SMB and HML portfolios were obtained from Ken French's web site at

(2) http://web.mit.edu/kfrench/www/data.library.html. Fama and French (1993) describe the construction of these portfolios.

(3) Returns data on Bonds are from the Center for Research in Security Prices.

(4) All industry-level return series are constructed from value-weighted portfolios of firm-level equity returns in the Center for Research in Security Prices database. See Davis and Willen (2000), especially Appendix A, for further explanation.

(5) Nominal returns for the industry-level measures were converted to real returns using the GDP deflator for personal consumption expenditures.

(6) There were insufficient firm-level equity securities to construct the returns for Health in 1968 or for Technical in 1987 and 1988. These data points are missing.

(7) The last column lists the occupation for which we tried the returns measure as a regressor 
Table 6: Occupation-Level Earnings Innovations Regressed on SMB Portfolio Returns, 1968-1994

\begin{tabular}{lllllll}
\hline \hline & Natural Units Wage Measure & & \multicolumn{2}{l}{ Natural Log Wage Measure } \\
\hline Occupational Description & $\begin{array}{l}\text { Slope } \\
\text { Coefficient }\end{array}$ & $\begin{array}{l}\text { Standard } \\
\text { Error }\end{array}$ & $\begin{array}{l}\text { R-squared } \\
\text { Value }\end{array}$ & $\begin{array}{l}\text { Slope } \\
\text { Coefficient X } \\
1000\end{array}$ & $\begin{array}{l}\text { Standard } \\
\text { Error X 1000 }\end{array}$ & $\begin{array}{l}\text { R-squared } \\
\text { Value }\end{array}$ \\
\hline \hline Accountants and Auditors & -25.2 & 12.4 & .14 & -1.0 & 0.5 & .11 \\
Electrical Engineers & -30.6 & 14.6 & .11 & -0.9 & 0.4 & .09 \\
Registered Nurses & -3.8 & 5.5 & .02 & -0.2 & 0.4 & .01 \\
Teachers, Elementary & -13.1 & 5.9 & .13 & -0.8 & 0.3 & .16 \\
Teachers, Secondary & -16.9 & 7.1 & .15 & -0.9 & 0.4 & .14 \\
Janitors and Cleaners & -13.5 & 6.7 & .10 & -0.6 & 0.5 & .02 \\
Auto Mechanics & -3.9 & 8.8 & .01 & -0.4 & 0.5 & .02 \\
Electricians & 13.9 & 11.4 & .05 & & 0.4 & 0.4 \\
Plumbers & -25.4 & 17.3 & .08 & -1.5 & 0.8 & .03 \\
Truck Drivers & 2.2 & 9.8 & .00 & -0.1 & 0.5 & .12 \\
\hline \hline
\end{tabular}

Source: Authors' calculations.

Notes:

(1) All regressions are estimated by ordinary least squares.

(2) The dependent variables are the innovations from the fitted time-series processes in Table 2 (Natural Units) and Table 3 (Natural Logs). 
Table 7: Occupation-Level Earnings Innovations Regressed on Best-Fitting Set of Asset Returns, Natural Units Wage Measure, 19681994

\begin{tabular}{|c|c|c|c|c|c|c|}
\hline \multirow[t]{2}{*}{ Occupational Description } & \multicolumn{4}{|c|}{ Slope Coefficient (Standard Error) } & \multirow{2}{*}{$\begin{array}{l}\text { Industry } \\
\text { Measure }\end{array}$} & \multirow[t]{2}{*}{ R-squared } \\
\hline & SMB & HML & Bonds & Industry & & \\
\hline Accountants and Auditors & $-25.2(12.4)$ & & & & & .14 \\
\hline Electrical Engineers & $-47.0(19.2)$ & & & $13.9(10.7)$ & Build & .20 \\
\hline Registered Nurses & & & $16.1(8.2)$ & $-1.9(2.3)$ & Health & .15 \\
\hline Teachers, Elementary & $-22.3(9.2)$ & & & $5.0(3.9)$ & Educ & .22 \\
\hline Teachers, Secondary & $-32.3(10.7)$ & & & 8.4 (4.7) & Educ & .29 \\
\hline Janitors and Cleaners & $-13.5(6.7)$ & & & & & .14 \\
\hline Auto Mechanics & & & & & & -- \\
\hline Electricians & & & $-34.4(16.3)$ & $11.7 \quad(5.9)$ & Build & .23 \\
\hline Plumbers & $-47.5(22.9)$ & & $-35.7(26.7)$ & $17.9(12.9)$ & Build & .19 \\
\hline Truck Drivers & & $11.6(11.3)$ & $-27.3(14.4)$ & & & .14 \\
\hline
\end{tabular}

Source: Authors' calculations.

Notes:

(1) All regressions are estimated by ordinary least squares.

(2) The dependent variables are the innovations from the fitted time-series processes in Table 2.

(3) No asset return measure is statistically significant in the regression for Auto Mechanics. 
Table 8: Occupation-Level Earnings Innovations Regressed on Best-Fitting Set of Asset Returns, Natural Log Wage Measure, 19681994

\begin{tabular}{|c|c|c|c|c|c|c|}
\hline \multirow[t]{2}{*}{ Occupational Description } & \multicolumn{4}{|c|}{ Slope Coefficient (Standard Error) } & \multirow{2}{*}{$\begin{array}{l}\text { Industry } \\
\text { Measure }\end{array}$} & \multirow[t]{2}{*}{ R-squared } \\
\hline & SMB & HML & Bonds & Industry & & \\
\hline Accountants and Auditors & $-1.4(0.6)$ & & & $0.5(0.5)$ & Finance & .19 \\
\hline Electrical Engineers & $-1.3(0.6)$ & & & $0.4(0.3)$ & Build & .18 \\
\hline Registered Nurses & & & $1.0(0.6)$ & & & .10 \\
\hline Teachers, Elementary & $-0.8(0.3)$ & & & & & .20 \\
\hline Teachers, Secondary & $-1.7(0.6)$ & & & $0.4(0.2)$ & Educ & .28 \\
\hline Janitors and Cleaners & $-0.6(0.5)$ & & & & & .06 \\
\hline Auto Mechanics & & & & & & -- \\
\hline Electricians & & & $-1.9(0.6)$ & $0.5(0.2)$ & Build & .35 \\
\hline Plumbers & $-2.4(1.0)$ & & $-2.5(1.2)$ & $0.8(0.6)$ & Build & .28 \\
\hline Truck Drivers & & $0.8(0.6)$ & $-1.6(0.8)$ & & & .18 \\
\hline
\end{tabular}

Source: Authors' calculations.

Notes:

(1) All regressions are estimated by ordinary least squares.

(2) The dependent variables are the innovations from the fitted time-series processes in Table 3.

(3) No asset return measure is statistically significant in the regression for Auto Mechanics. 
Table 9: Investment in risky assets with zero covariance between earnings and returns: Two-fund separation.

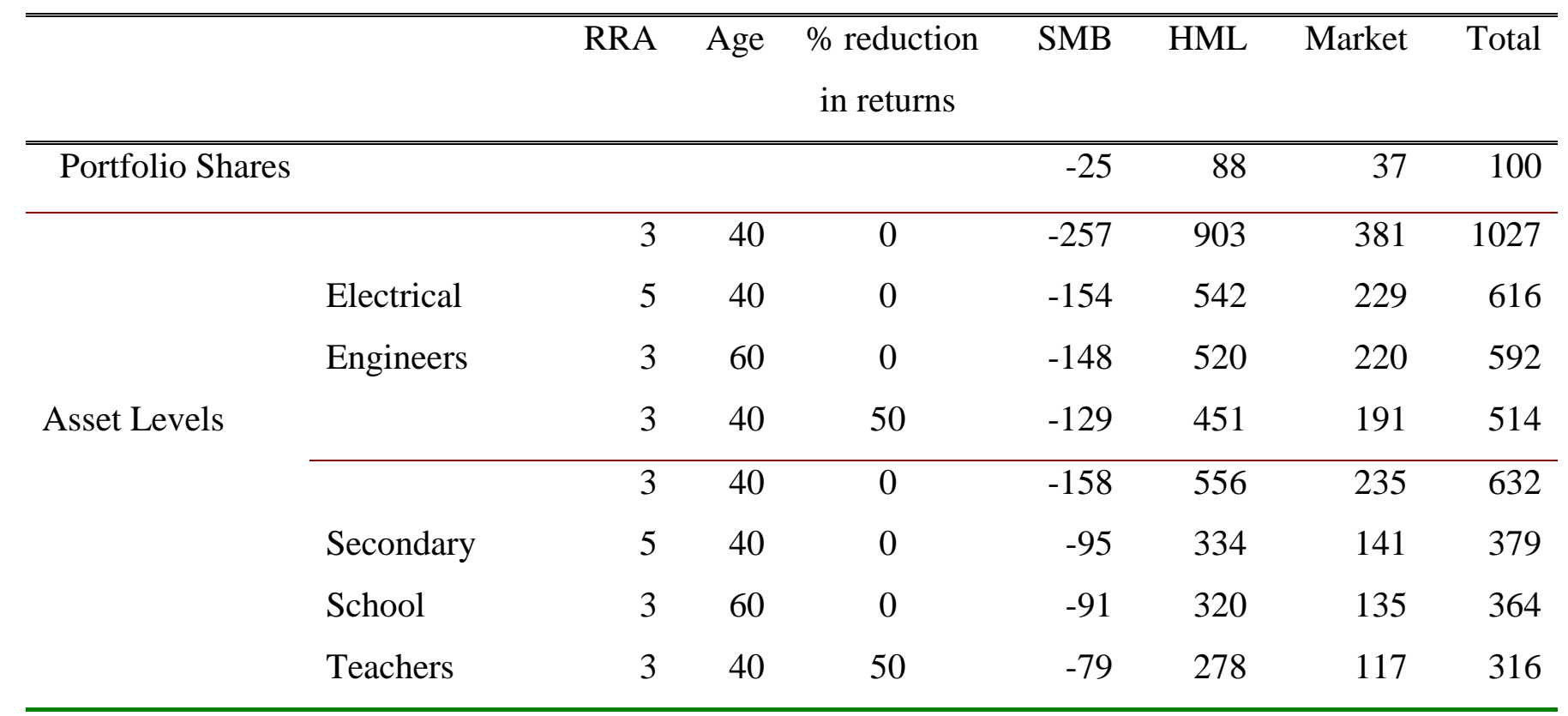

Source: Authors' calculations.

Notes:

1. Portfolio shares are percentage of total investment in risky assets.

2. Asset levels are in thousands of 1982 dollars.

3. RRA stands for relative risk aversion level. 
Table 10: Endowed exposure, desired exposure and portfolio holdings.

\begin{tabular}{|c|c|c|c|c|c|}
\hline & & SBM & HML & Market & Total \\
\hline Accountants and & Endowed exposure & -36 & 0 & 0 & -36 \\
\hline \multirow[t]{2}{*}{ Auditors } & Desired exposure & -189 & 662 & 280 & 753 \\
\hline & Portfolio Position & -153 & 662 & 280 & 789 \\
\hline \multirow[t]{3}{*}{ Electrical Engineers } & Endowed exposure & -28 & 0 & 0 & -28 \\
\hline & Desired exposure & -257 & 903 & 381 & 1027 \\
\hline & Portfolio Position & -229 & 903 & 381 & 1055 \\
\hline Elementary School & Endowed exposure & -42 & 0 & 0 & -42 \\
\hline \multirow[t]{2}{*}{ Teachers } & Desired exposure & -139 & 488 & 206 & 555 \\
\hline & Portfolio Position & -97 & 488 & 206 & 597 \\
\hline Secondary School & Endowed exposure & -52 & 0 & 0 & -52 \\
\hline \multirow[t]{2}{*}{ Teachers } & Desired exposure & -158 & 556 & 235 & 632 \\
\hline & Portfolio Position & -106 & 556 & 235 & 684 \\
\hline \multirow[t]{3}{*}{ Janitors and Cleaners } & Endowed exposure & -13 & 0 & 0 & -13 \\
\hline & Desired exposure & -90 & 315 & 133 & 359 \\
\hline & Portfolio Position & -76 & 315 & 133 & 372 \\
\hline \multirow[t]{3}{*}{ Plumbers } & Endowed exposure & -46 & 0 & 0 & -46 \\
\hline & Desired exposure & -170 & 597 & 252 & 679 \\
\hline & Portfolio Position & -124 & 597 & 252 & 725 \\
\hline
\end{tabular}




\begin{tabular}{llllll} 
Truck Drivers & Endowed exposure & -0 & 16 & -0 & 16 \\
& Desired exposure & -141 & 497 & 210 & 565 \\
& Portfolio Position & -141 & 481 & 210 & 550 \\
\hline \hline
\end{tabular}

Source: Authors' calculations.

Notes:

(1) Table entries show the endowed exposure, desired exposure and optimal portfolio position for the indicated risky assets in thousands of 1982 dollars.

(2) All calculations assume a 40-year old investor who has a relative risk aversion of 3.

(3) See text for additional details. 
Table 11: Risk aversion, excess returns and optimal portfolio shares in the case of three risky assets

\begin{tabular}{llllll}
\hline \hline & $\begin{array}{l}\text { Percentage } \\
\text { Reduction } \\
\text { in Excess }\end{array}$ & RRA & SMB & HML & Market \\
& Returns & & & & \\
\hline Accountants and & 0 & 3 & -19 & 84 & 35 \\
Auditors & 50 & 5 & -8 & 76 & 32 \\
& 75 & 5 & 5 & 67 & 28 \\
\hline Electrical Engineers & 0 & 3 & -22 & 86 & 36 \\
& 50 & 5 & -15 & 81 & 34 \\
\hline Elementary School & 75 & 5 & -6 & 75 & 31 \\
Teachers & 0 & 3 & -16 & 82 & 35 \\
& 50 & 5 & 0 & 70 & 30 \\
\hline Secondary School & 75 & 5 & 17 & 58 & 25 \\
Teachers & 0 & 3 & -16 & 81 & 34 \\
& 50 & 5 & 2 & 69 & 29 \\
\hline Janitors and Cleaners & 0 & 5 & 19 & 57 & 24 \\
\hline Plumbers & 75 & 3 & -21 & 85 & 36 \\
& 50 & 5 & -11 & 78 & 33 \\
& 75 & 5 & -0 & 70 & 30 \\
\hline Truck Drivers & 0 & 3 & -17 & 82 & 35 \\
& 50 & 5 & -2 & 72 & 30 \\
\hline & 75 & 5 & 14 & 61 & 26 \\
\hline
\end{tabular}

Source: Authors' calculations. 
Notes:

(1) A "Percent Reduction In Excess Returns" of 0 means that the expected returns on risky assets are set to their realized sample values. A 50 percent reduction means that the realized excess return (sample mean return minus a risk-free rate of $3.5 \%$ ) is set to half its sample value, and similarly for a 75 percent reduction.

(2) RRA stands for relative risk aversion level.

(3) The entries in the last three columns show the percentage of risky financial asset holdings in the indicated asset.

(4) All calculations assume an investor who is 40 years old.

(5) See text for additional details. 
Table 12: Endowed exposure to occupation-specific assets

\begin{tabular}{lccccccc}
\hline & \multicolumn{3}{c}{ Age } & \multicolumn{2}{c}{ Asset } \\
& 30 & 35 & 40 & 45 & 50 & 55 & \\
\hline Electrical Engineers & 9.5 & 8.9 & 8.2 & 7.4 & 6.4 & 5.2 & Build \\
Registered Nurses & -6.7 & -6.0 & -5.1 & -4.1 & -2.9 & -1.4 & Health \\
Elementary School & 12.2 & 10.9 & 9.4 & 7.7 & 5.5 & 3.0 & Educ \\
Teachers & & & & & & & Educ \\
Secondary School & 17.2 & 15.5 & 13.5 & 11.1 & 8.3 & 4.9 & \\
Teachers & & & & & & Build \\
Electricians & 14.5 & 13.3 & 11.9 & 10.2 & 8.2 & 5.8 & Build \\
Plumbers & 21.2 & 19.5 & 17.3 & 14.8 & 11.8 & 8.2 & \\
\hline
\end{tabular}

Source: Authors' calculations.

Notes:

1. The table entries report the endowed exposure to the indicated asset based on the best-fitting regression specification reported in Table 6.

2. See text for additional details 

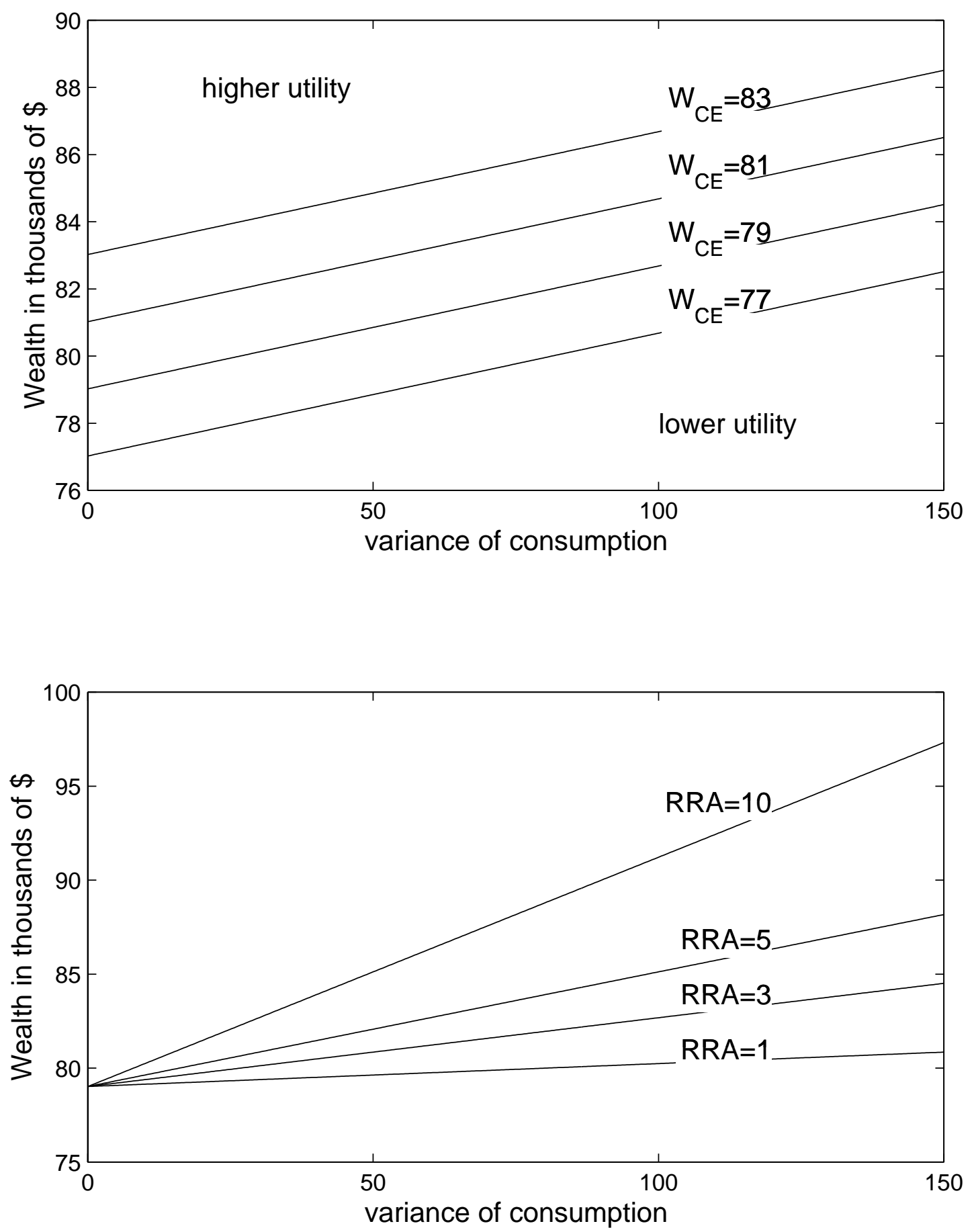

Figure 1: Indifference curves for an investor with $\$ 40,000$ a year in income. Upper panel shows indifference equivalent to different levels of wealth with certainty. Lower panel shows indifference curves equivalent to the same level of wealth with certainty for investors with different levels of relative risk aversion. 

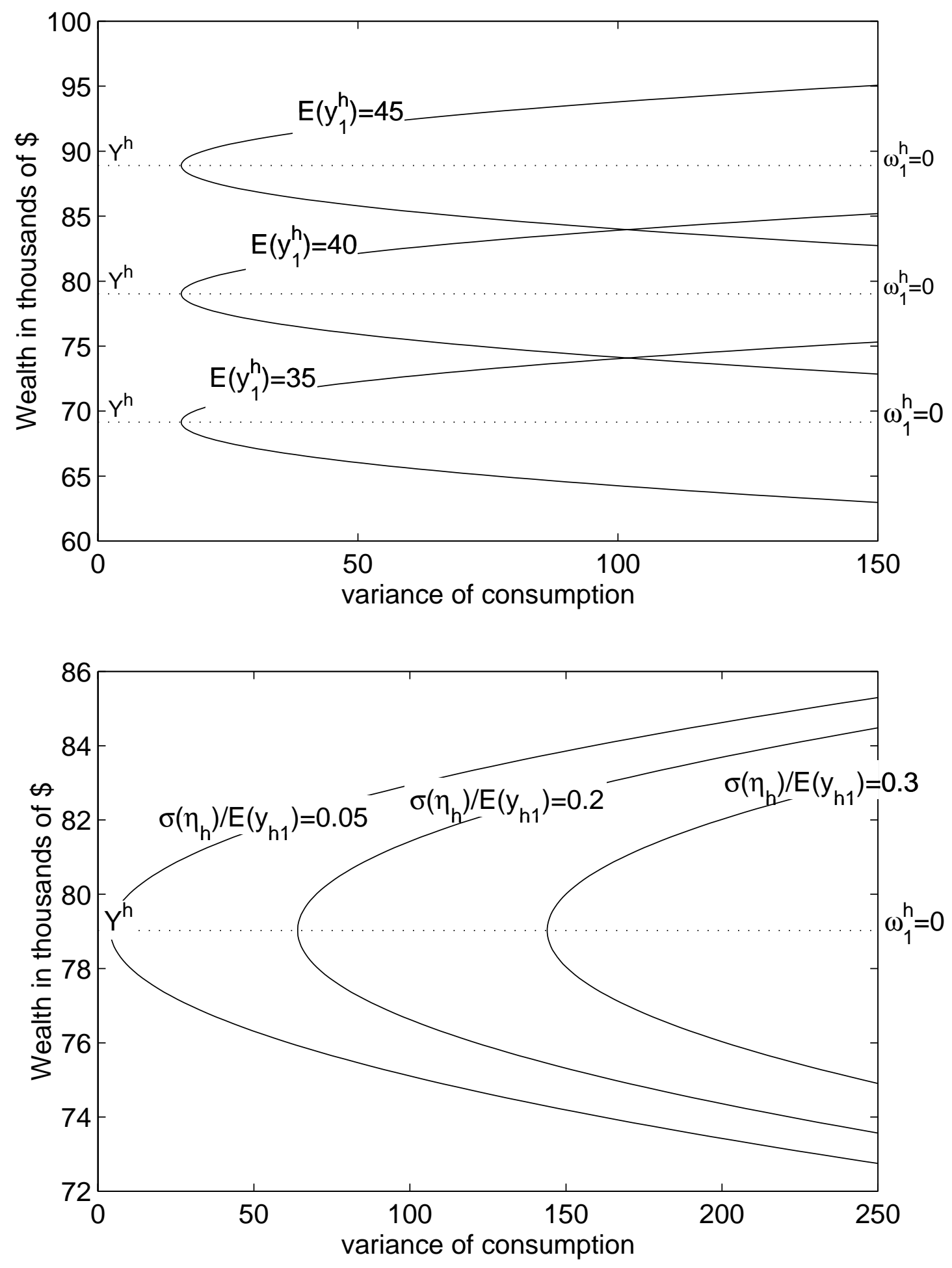

Figure 2: The "feasible set" under various different assumptions about asset returns and investor income. Unless otherwise noted, $y_{0}^{h}=E\left(\tilde{y}_{1}^{h}\right)=\$ 40,000, R_{0}=1.025$, $\sigma\left(\eta_{1}^{h}\right) / E\left(\tilde{y}_{1}^{h}\right)=.2, E\left(\tilde{R}_{1}\right)-\bar{R}_{0}=0.06, \operatorname{cov}\left(\tilde{\eta}_{1}^{h}, \tilde{R}_{1}\right)=0$. 

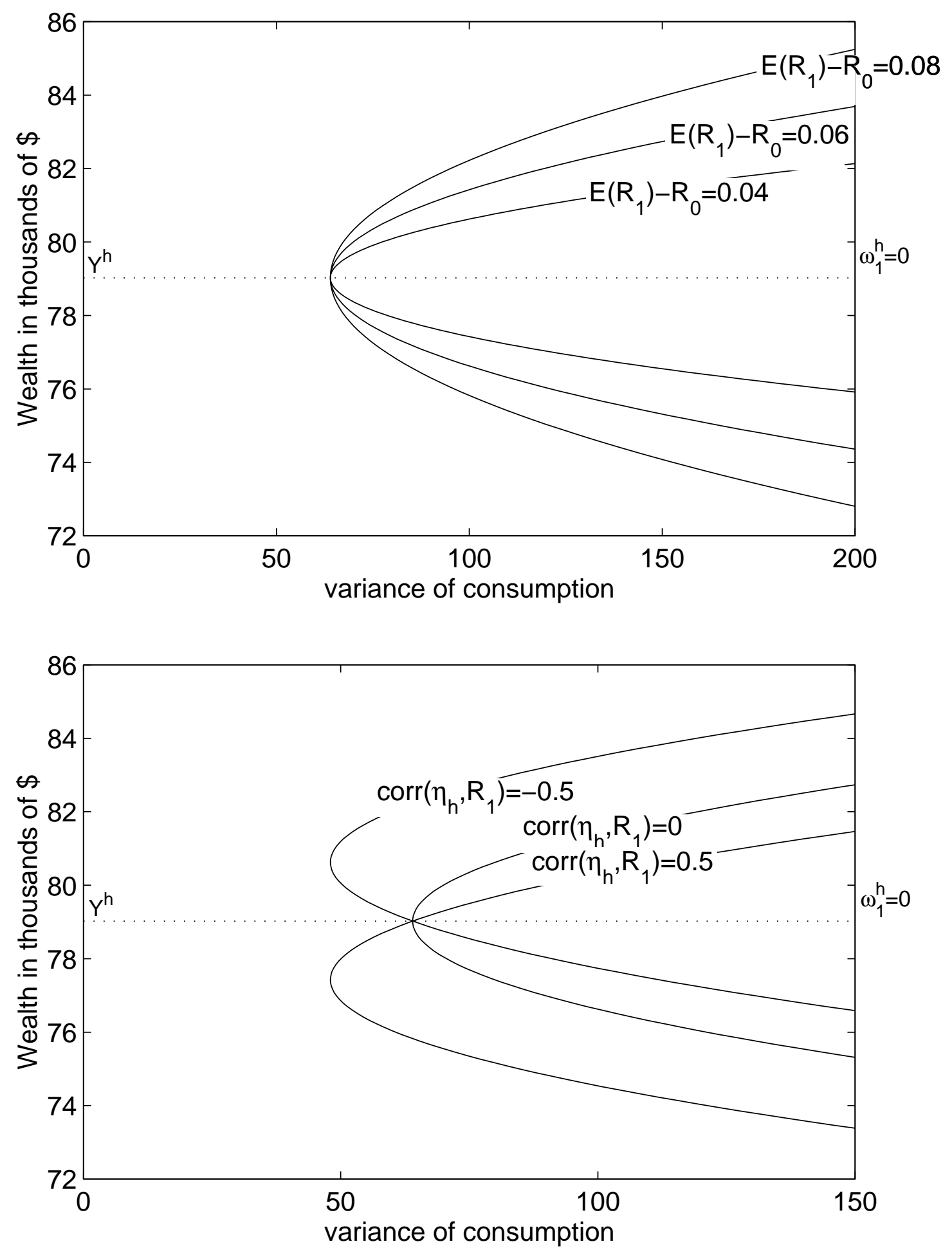

Figure 3: The "feasible set" under various different assumptions about asset returns and investor income. 

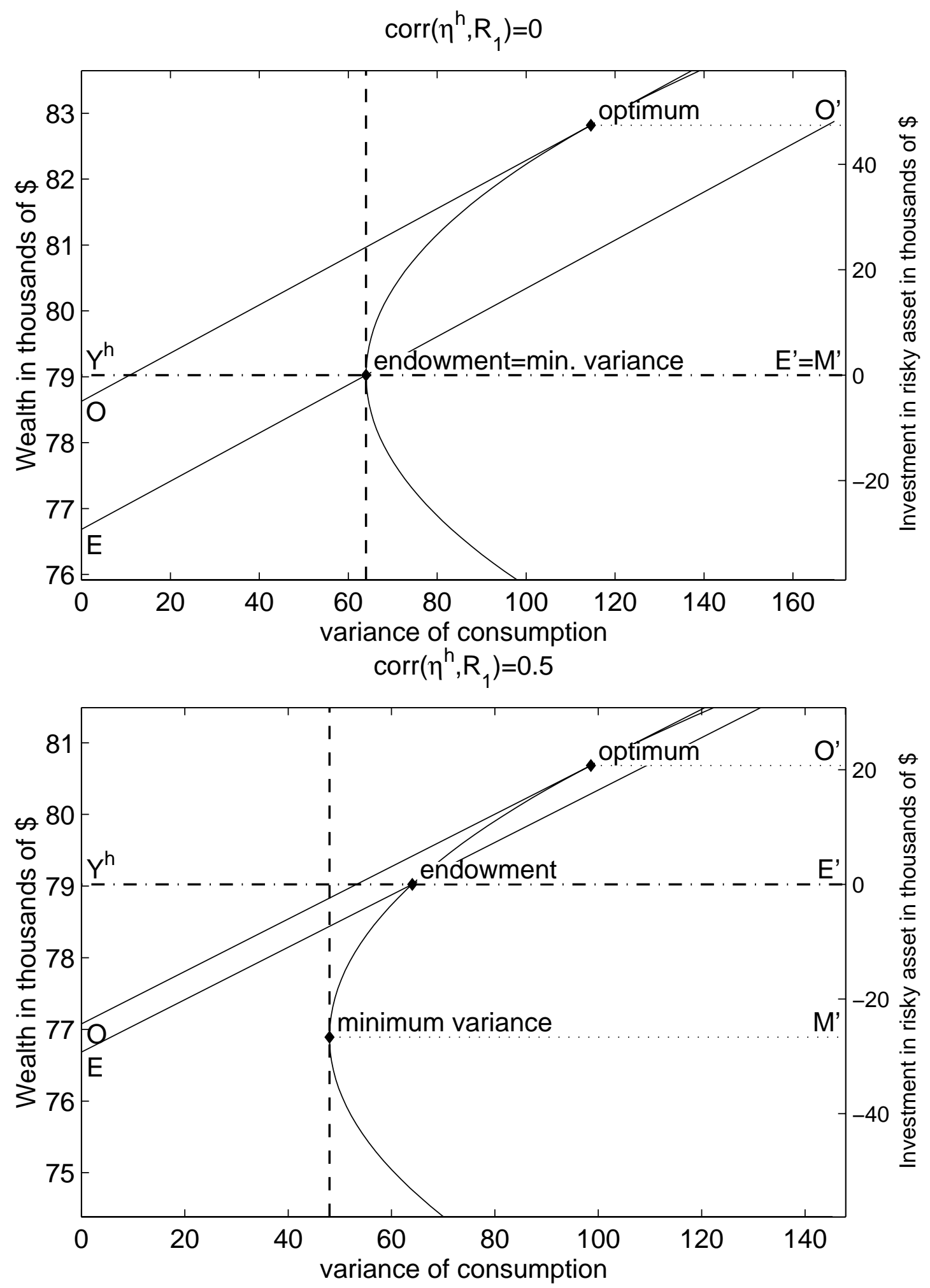

Figure 4: Portfolio choice under various assumptions about correlation between labor income and asset returns. The distance \$M'O'\$ is “desired exposure." \$M'E'\$ is "endowed exposure." Portfolio demand is \$E'O'\$. Other parameters are as in Figure 2 

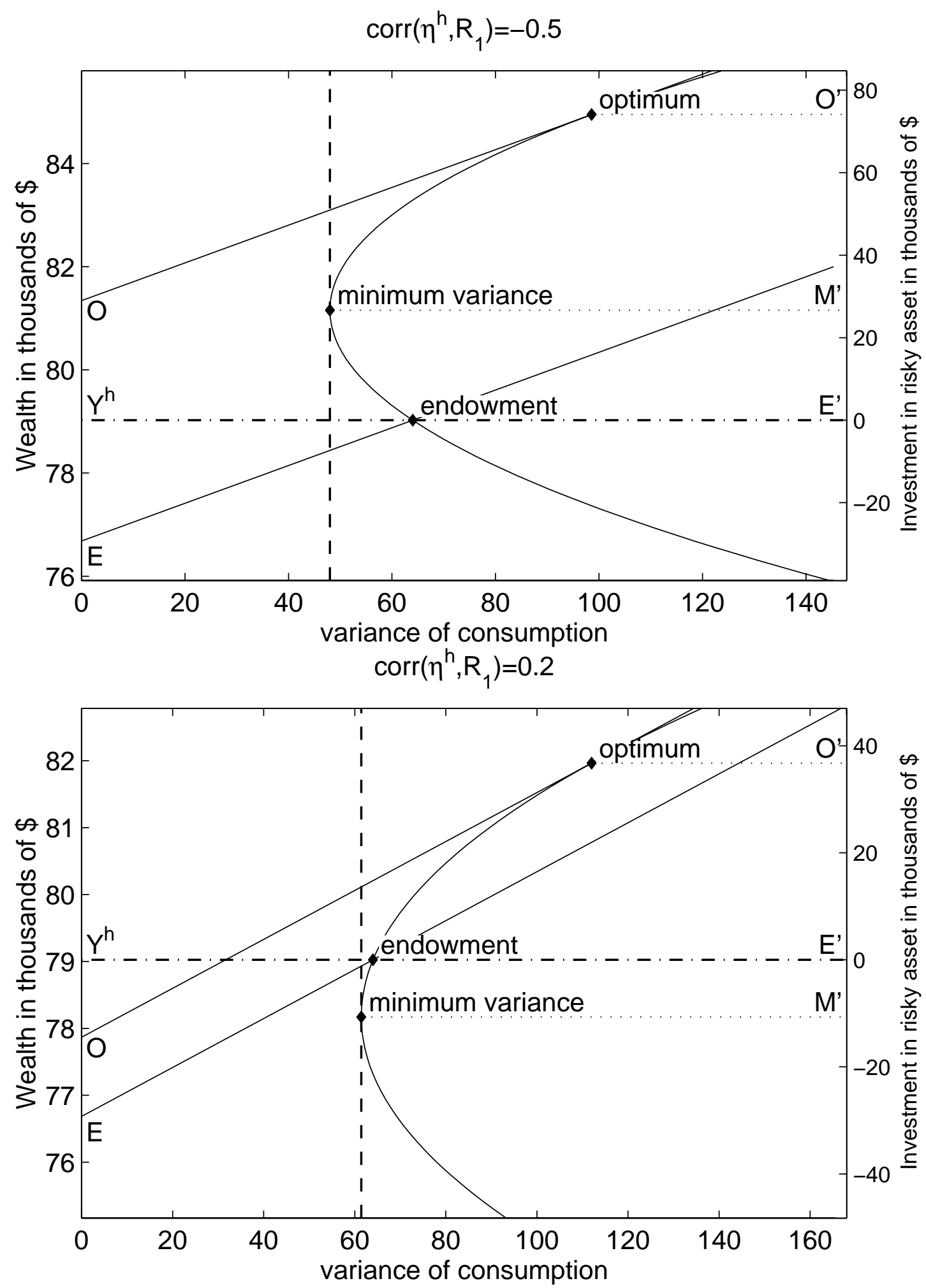

Figure 5:Portfolio choice under various assumptions about correlation between labor income and asset returns. The distance M'0' is “desired exposure." M'E' is “endowed exposure." Portfolio demand is E'O'. Other parameters are as in Figure 4. 


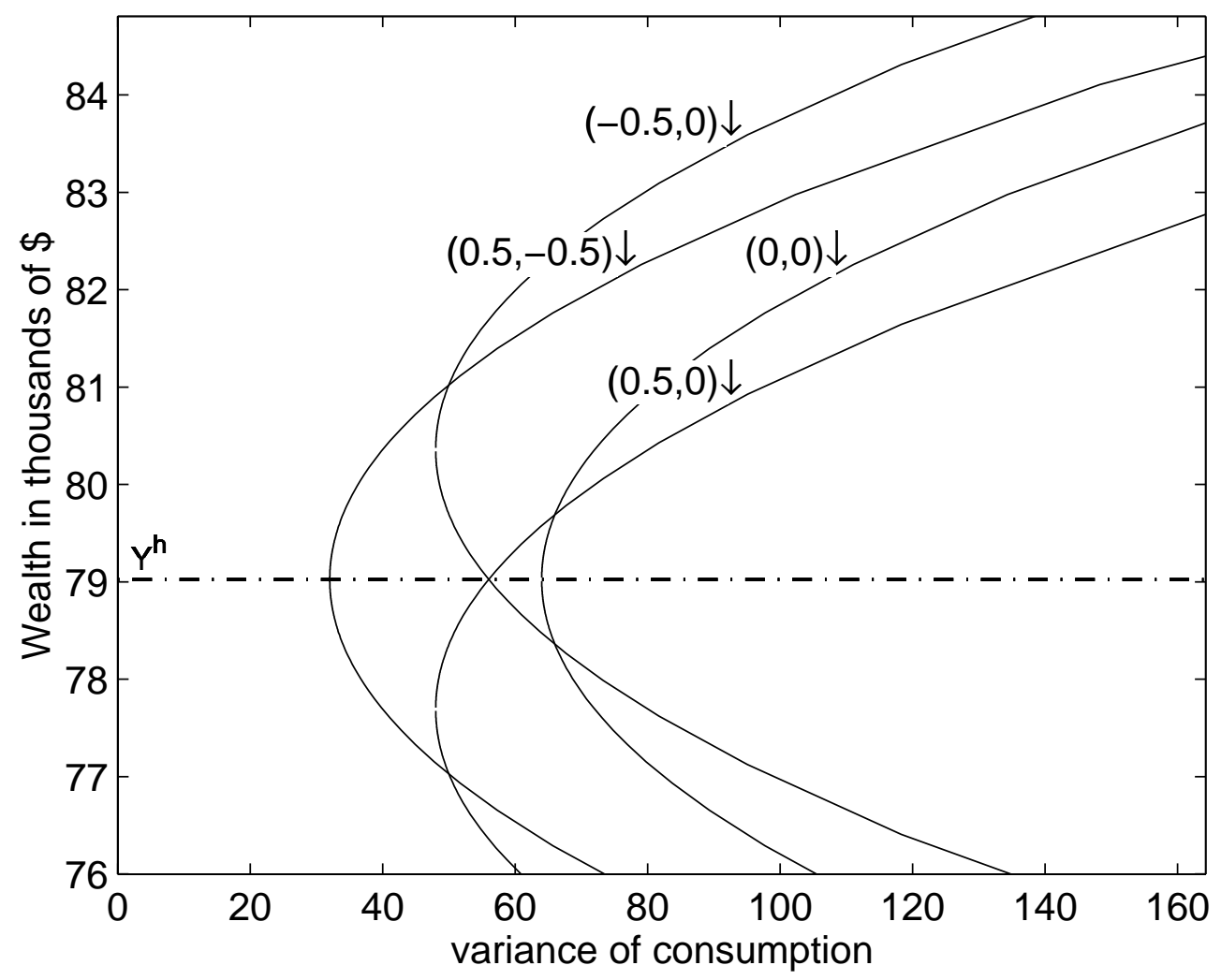

Figure 6: Feasible sets for four different investors when there are two risky financial assets. The numbers beside the curves are the correlations of labor income with the first and second asset respectively for each investor. 

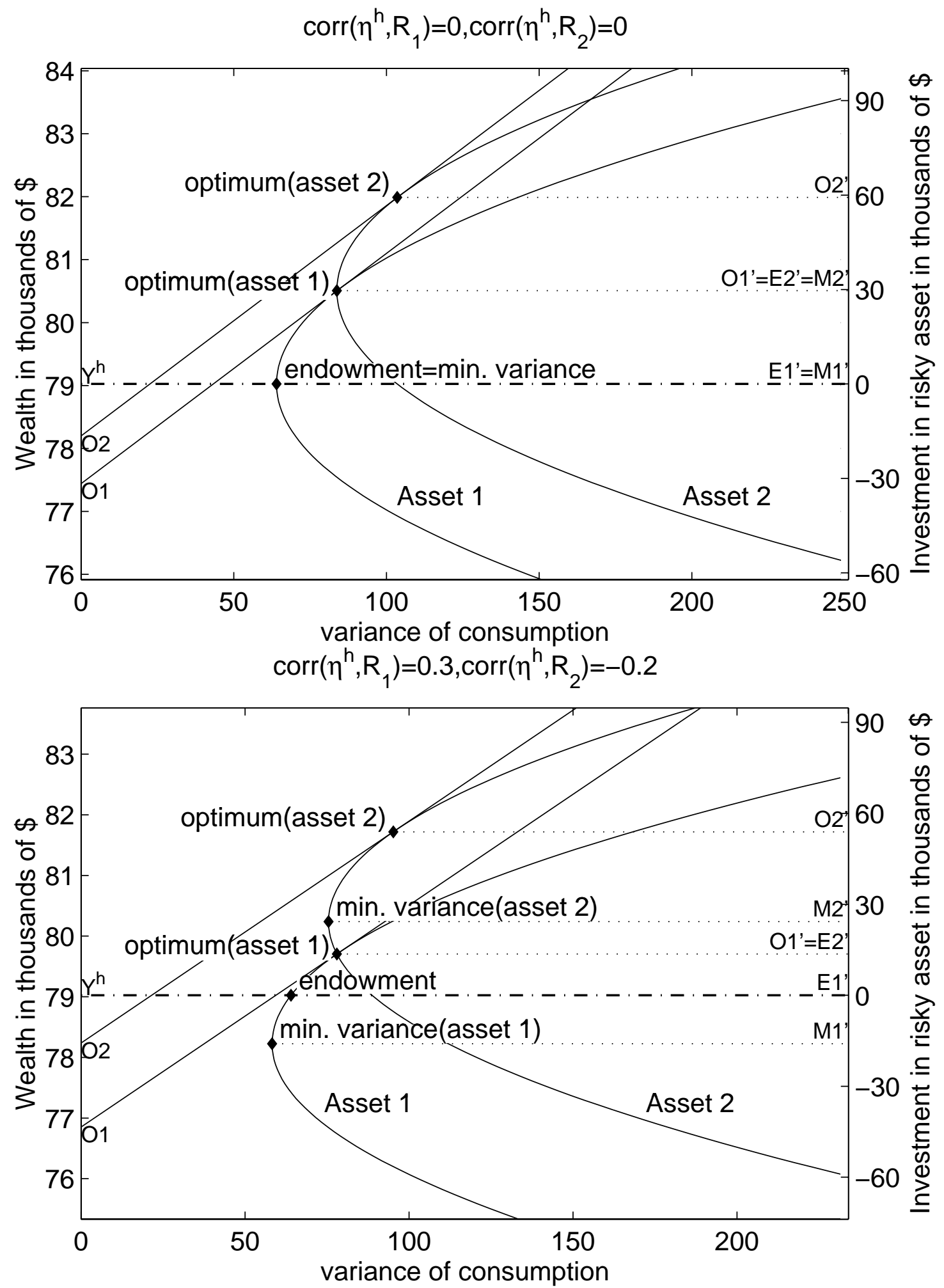

Figure 7: Portfolio choice with two uncorrelated assets. Upper panel shows an investor whose income is uncorrelated with both assets. Lower panels shows an investor whose labor income is correlated with both assets. 
Effect of a dollar shock to income on the PDV of earnings at different horizons

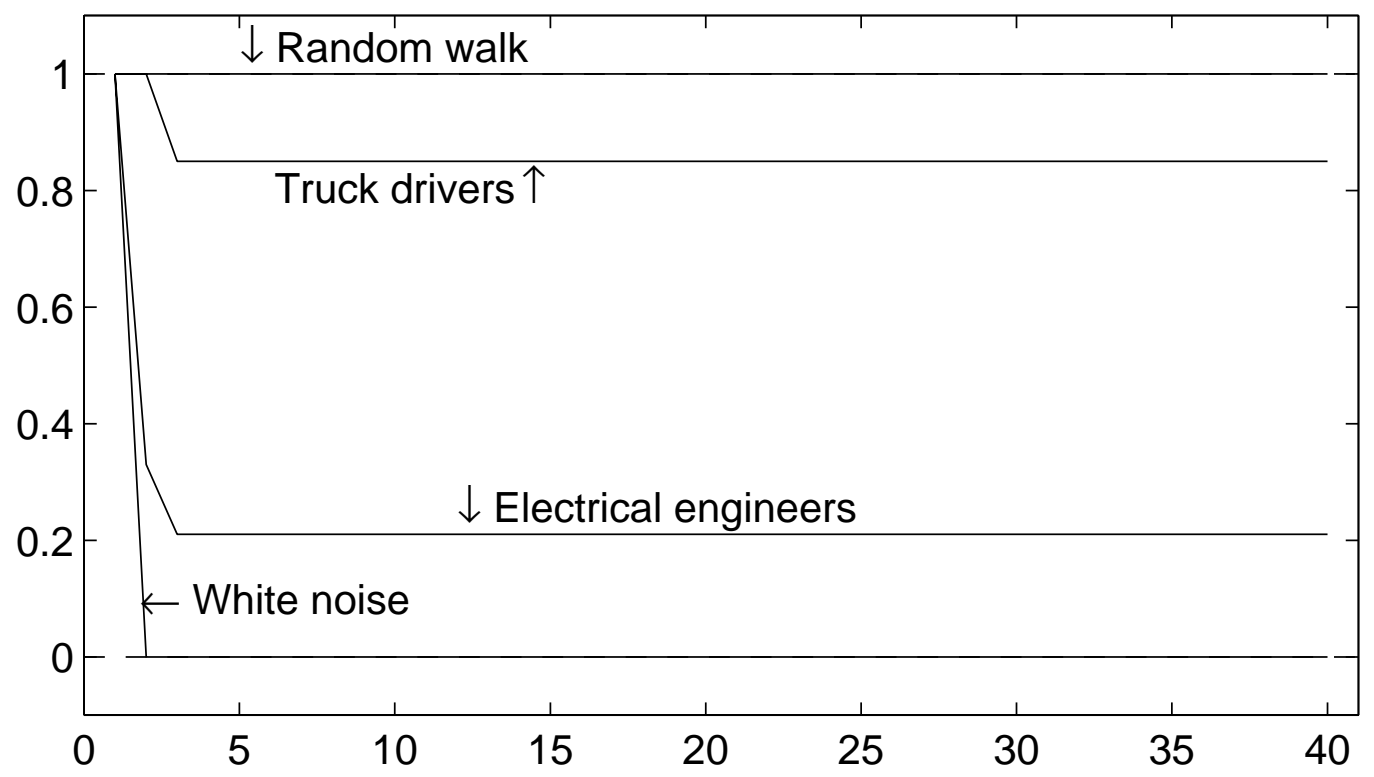

Effect of a dollar shock to earnings on wealth over the life cycle

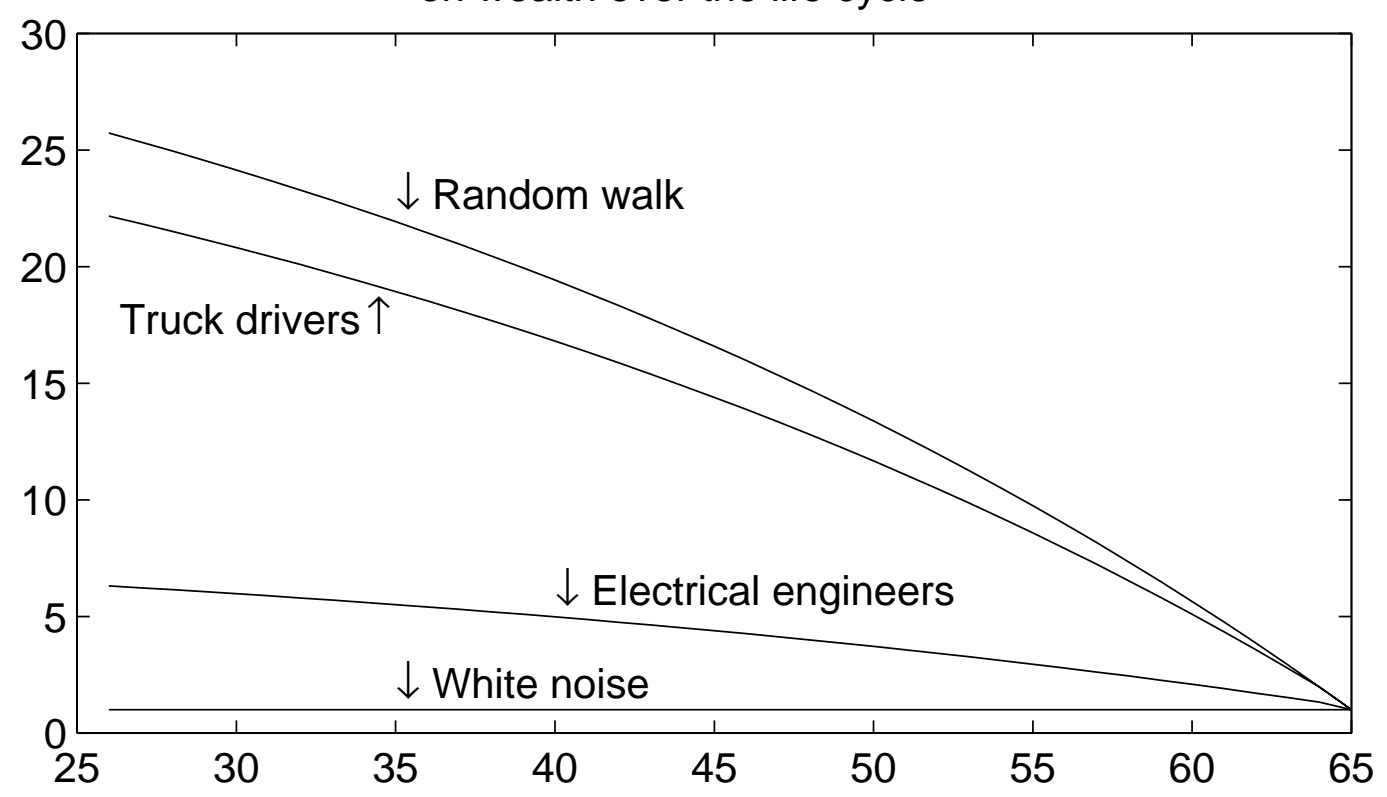

Figure 8: Effects of a shock to labor income on wealth. The top panel shows the effect of a dollar positive shock to income on expectations of future income. The bottom, shows the present discounted value of the sum of those changes - and shows the effect on wealth of a dollar shock to current income. 